\title{
SEGURANÇA PÚBLICA E CIDADES: PERSPECTIVAS A PARTIR DA ESCOLA DE CHICAGO.
}

\section{PUBLIC SAFETY AND CITIES: PERSPECTIVES FROM THE CHICAGO SCHOOL.}

\section{Claudio Alberto Gabriel Guimarães ${ }^{1}$ Thayara Castelo Branco ${ }^{2}$ Antonio Eduardo Santoro ${ }^{3}$}

Se um homem define uma situação como real, ela se torna real em suas consequências. Thomas (1923).

\section{RESUMO}

Pretende-se com este trabalho, a partir da perspectiva teórica desenvolvida pela Escola Sociológica de Chicago, investigar e resgatar os estudos realizados desde o início do Século XX, que indicam a configuração espacial das cidades como fator inibidor ou potencializador da atividade criminosa, a depender do seu nível de organização social e urbanística. Sequencialmente, a partir de estudos de pesquisadores brasileiros, intenta-se averiguar a pertinência da inter-relação entre desorganização social, desorganização urbana e criminalidade no país, o que leva a seguinte problematização: Existe relação entre espaços da cidade desorganizados social e urbanisticamente e o cometimento de delitos? Por fim, serão estudadas as previsões legais, a partir da Constituição brasileira, acerca do desenvolvimento de políticas públicas em tal âmbito urbano, como forma de combate à violência apontada pela pesquisa como setorizada social e espacialmente. O método de pesquisa utilizado foi estritamente a pesquisa bibliográfica e, consequentemente, os dados utilizados os que constantes nos

\footnotetext{
1 Promotor de Justiça do Estado do Maranhão. Doutor em Direito Público pela Universidade Federal de Pernambuco, com área de concentração em Direito Penal. Doutor em Direito pela Universidade Federal de Santa Catarina, com área de concentração em Criminologia. Pós-Doutorando pela Universidade de Lisboa com área de estudos em Teoria da Pena. Professor Pesquisador do CNPq e UNICEUMA. Professor Adjunto da Universidade Federal do Maranhão dos cursos de graduação e do Programa de Mestrado em Direito e Instituições do Sistema de Justiça. Afiliação: Universidade Federal do Maranhão - UFMA e Universidade Ceuma - UNICEUMA Lattes Lattes: http://lattes.cnpq.br/7560021977120603 ORCID: https://orcid.org/0000-0003-3790-8808 E-mail:calguimaraes@yahoo.com.br

${ }^{2}$ Advogada. Doutora e Mestra em Ciências Criminais pela PUCRS, com área de pesquisa em violência, crime e segurança pública. Especialista em Ciências Criminais pelo CESUSC. Professora da graduação e da pós-graduação da Universidade CEUMA - UNICEUMA. Coordenadora da Pós-Graduação em Ciências Criminais da Universidade CEUMA - UNICEUMA. Afiliação: Universidade Ceuma - UNICEUMA Lattes: http://lattes.cnpq.br/ 7047843216689603 ORCID: https://orcid.org/0000-0002-4653-0061 E-mail: thaybranco@yahoo.com.br

${ }^{3}$ Advogado Criminalista, Mestre e Doutor pela Universidade Federal do Rio de Janeiro, Doutor pela Universidade de Coimbra, Professor Adjunto do Programa de Pós-Graduação em Direito da Universidade Federal do Rio de Janeiro, Professor Titular do IBMEC/RJ. Afiliação: Universidade Federal do Rio de Janeiro - UFRJ Lattes: http://latt es.cnpq.br/9190879263950156 ORCID: https://orcid.org/0000-0003-4485-844X E-mail: antoniosantoro@anto niosantoro.com.br
} 
trabalhos referidos e que acabaram por apontar como hipótese a plausibilidade na ligação entre desorganização social, desorganização urbana e criminalidade sugerindo, de forma conclusiva mas não exaustiva, a necessidade de implementação de políticas públicas inclusivas, principalmente no âmbito dos Municípios, focadas no combate à violência estrutural e, consequentemente, criminal.

Palavras-chave: Escola de Chicago; desorganização social, desorganização urbana; políticas públicas; criminalidade.

\section{ABSTRACT}

The aim of this work is, from the theoretical perspective developed by the Sociological School of Chicago, to investigate and rescue the studies conducted since the early twentieth century, which indicate the spatial configuration of cities as a factor inhibiting or enhancing criminal activity, depending on of their level of social and urban organization. Sequentially, based on studies by Brazilian researchers, it is intended to investigate the relevance of the interrelationship between social disorganization, urban disorganization and crime in the country, which leads to the following problematization: There is a relationship between socially and urbanistically disorganized city spaces and committing crimes? Finally, we will study the legal predictions, based on the Brazilian Constitution, about the development of public policies in such urban context, as a way to combat the violence pointed out by the research as socially and spatially sectorized. The research method used was strictly the bibliographic research and, consequently, the data used in the referred works and that pointed as hypothesis the plausibility in the connection between social disorganization, urban disorganization and crime suggesting, conclusively but not exhaustively, the need to implement inclusive public policies, especially within municipalities, focused on combating structural and, consequently, criminal violence. Keywords: Chicago School; social disorganization, urban disorganization; public policy; crime.

\section{INTRODUÇÃO}

A história da humanidade é marcada por grandes êxodos, não sendo, portanto, algo recente o fenômeno do deslocamento de um grande contingente de pessoas dentro e fora de determinadas fronteiras nacionais - o que está intimamente relacionado às dimensões territoriais do país -, pelos mais variados motivos, que vão desde catástrofes naturais, geralmente acompanhas por fome e doenças até, mais comumente, a guerra.

É bem sabido que o Brasil é um país continental e que nas últimas décadas tem sido marcado, também, por um intenso fluxo migratório. Entretanto, tal deslocamento destes contingentes humanos está a ocorrer mais acentuadamente dentro das próprias fronteiras e por motivos que nada têm a ver 
com a guerra ou catástrofes naturais, embora não se possa afastar a hipótese das doenças e da fome, vez que ainda são encontrados no país rincões caracterizados pela extrema pobreza, cujas consequências, além das já descritas, se estendem pelas esferas das prestações públicas básicas que devem ser garantidas pelo Estado.

Desse modo, podemos aventar como hipótese que as principais causas da intensa migração interna brasileira está ligada às questões de ordem social e urbana, o que pode ser comprovado pelo hiato existente entre o previsto como direitos fundamentais nessa área da Constituição Federal e aquilo que permeia a realidade de grande parte da população do país.

Tal movimento migratório - independentemente das acaloradas discussões teóricas existentes sobre suas razões -, como é de praxe, traz a reboque várias consequências e uma das mais desfavoráveis ao país é o inchaço das cidades com maior estrutura urbana e, portanto, com maior número de habitantes, normalmente localizadas próximas às áreas industrializadas e com intenso fluxo no setor de serviços.

A razão de tal concentração populacional talvez tenha sua explicação nos próprios cânones do urbanismo moderno, vez que também é por demais conhecido o quadro fundacional deste, disposto na Carta de Atenas do ano de 1943, que aponta o caminho da organização e interação dos espaços comuns à cidade - zoneamento com distribuição programática -, que devem se constituir em setores distintos de moradia, trabalho, lazer e circulação, como a melhor forma para que seus habitantes garantam a fruição das vantagens que a convivência coletiva planejada possa assegurar.

Por evidente que, pelos mais variadas razões, nem todas as cidades, ou mesmo a maioria destas no Brasil, conseguiram se estruturar nesse sentido, existindo na realidade uma profunda carência de infraestrutura urbana no país.

Desta forma, uma considerável parcela da população brasileira tem deixado as áreas mais carentes de recursos, mormente as rurais, locais onde existe um profundo déficit de organização urbanística e, consequentemente, menores possibilidades de acesso às benesses dos grandes centros urbanos, como moradia, emprego, lazer, assistência de saúde, transporte público, saneamento básico, água encanada, eletricidade, dentre outros direitos constitucionais básicos, em direção às grandes cidades na busca por uma melhor qualidade de vida.

Tal quadro tem levado o país a um fenômeno conhecido por favelização, que é a criação de áreas habitadas não planejadas urbanisticamente - áreas naturais -, marcadas por uma intensa desorganização social e urbana, onde os níveis de violência são acentuados e seus moradores, via de regra, pertencentes aos estratos sociais menos favorecidos da população.

A reflexão que agora se inicia objetiva, precipuamente, investigar as razões pelas quais as pessoas em tal ambiência estão mais propensas a cometerem determinados tipos de delito, 
contribuindo para o desolador quadro da crescente criminalidade no Brasil, assim como, em uma linha pragmática, indicar caminhos que possam ajudar na solução de tão difícil problema.

Com o recorte temático que leva à averiguação da pertinência na inter-relação entre desorganização social, desorganização urbana e criminalidade no país, propomos a seguinte problematização: existe relação entre espaços da cidade desorganizados social e urbanisticamente e o cometimento de delitos?

Para enfrentamento de tal problematização, no que pertine à metodologia adotada no presente artigo, o método de abordagem utilizado será o indutivo, visto que se trata de pesquisa desenvolvida no campo teórico-interpretativo da realidade, partiremos daquilo por demais conhecido, sem estar adstrito a consensos, para chegarmos a ilações até então não realizadas; pela via do argumento, dessarte, buscaremos ampliar o que está estabelecido, rumando do conhecido para o desconhecido, do particular para o geral, com o objetivo último de elaborar uma forma de conhecimento que ultrapasse necessariamente o já estabelecido pelo senso comum ${ }^{4}$.

Utilizando como padrão para referências as normas da ABNT, sempre alicerçados na técnica de pesquisa bibliográfica, buscando uma ampla revisão das obras clássicas, assim como do que mais recentemente foi escrito sobre o assunto, adotamos como método de procedimento o monográfico, com a abordagem de um único tema, o que não impede um necessário e profícuo diálogo interdisciplinar, com contribuições oriundas da Ciência Política, da Filosofia, da Criminologia, da Geografia, da Epistemologia e da Sociologia.

A teoria de base encontra-se profundamente alicerçada em um viés de conhecimento especificamente construído a partir de aprofundados estudos no âmago das cidades, ou seja, o trabalho que agora se inicia será desenvolvido sob a perspectiva adotada pela sociologia desenvolvida na Universidade de Chicago para explicar os motivos pelos quais determinados crimes são cometidos e, consequentemente, sob a mesma perspectiva, a melhor maneira para enfrentar tais situações.

Por consequência, para dar sustentação à presente temática, imprescindível o rompimento com categorias tradicionais do Direito Penal, pautadas em perspectivas naturalistas ou ontológicas para explicação da prática delitiva e, assim, para nós, conceitos como os de desorganização social, desmoralização, assimilação, aculturação, ecologia espacial, ecologia humana, dominância, sucessão,

\footnotetext{
${ }^{4} \mathrm{~A}$ escolha do método indutivo deve-se ao entendimento teórico majoritário, segundo o qual, um sistema dedutivo, uma vez completos os axiomas que o põem em movimento, não admite acréscimos, inovações, aquilo que já é conhecido nada pode ser acrescentado de novo. Tal método de abordagem é utilizado quando se busca maiores explicações sobre um fenômeno, algo já contido nas premissas, mas ainda não percebido. Diferentemente da indução, é vedado acrescentar novas inferências, informação nova, dado que as conclusões estão, desde um primeiro momento, contidas nas premissas, o que significa que nada pode chegar de fora uma vez iniciado o mecanismo. Maior aprofundamento nas questões metodológicas, cfr. Bachelard (1999), Marconi e Lakatos (2000), Oliveira (2001), Leite (2001) e Pasold (2002).
} 
competição, dentre tantos outros, acabaram por desvelar um novo paradigma sobre o problema da criminalidade urbana, conferindo ao conjunto do saber produzido pelos sociólogos de Chicago o status de Escola científica 5 .

No que pertine ao eixo principal da presente temática, a Escola Sociológica de Chicago dando ênfase aos estudos das e nas cidades ${ }^{6}$, sistematiza que, em geral, o crime é um produto da desorganização social e urbana, resultado de problemas institucionais tanto na esfera pública quanto na privada, sustentando em tal linha de raciocínio que o crime se origina de déficits na esfera do controle social informal - família, escola, laços comunitários, religião, etc. - e na esfera da urbanização - áreas urbanas sujas, fétidas, degradadas, abandonadas pelo poder público, etc. - e não uma patologia individual ${ }^{7}$.

Centrando o foco nas pesquisas de campo, privilegiando o empirismo pela via da pesquisa qualitativa, os referidos sociólogos, ao estudarem o crime, perceberam que os ambientes socialmente desorganizados estavam fortemente encravados em locais com deficiências no planejamento e desenvolvimento urbanos, configurando-se como as áreas onde as estatísticas apontavam os maiores índices de cometimento de determinados tipos de crimes, mormente os violentos.

Com o objetivo de investigar a pertinência mínima dos fundamentos teóricos da sociologia produzida na Universidade de Chicago sintetizados acima, ou seja, buscar algum indicativo de plausibilidade de que a desorganização social está intimamente relacionada à desorganização urbana e que ambas contribuem para um considerável índice de criminalidade no Brasil, levamos a efeito uma ampla revisão bibliográfica sobre a temática em estudos realizados por pesquisadores brasileiros tendo como objeto espaços urbanos localizados no país.

Por fim, e seguindo a linha pragmática, também desenvolvida pelos sociólogos da Escola de Chicago, intentamos, a partir da Constituição Federal brasileira de 1988, encontrar soluções para o problema apresentado ${ }^{8}$, vez que nesta Carta Magna houve uma ampliação do reconhecimento dos

\footnotetext{
${ }^{5}$ Não vamos entrar no mérito das profundas e intensas discussões acadêmicas sobre a pertinência da atribuição de tal status. Becker (1996) aborda o tema, fazendo a distinção entre Escolas de Pensamento e Escolas de Atividade. Coulon (1995, p. 7) tem o seguinte entendimento: "Por 'Escola de Chicago' costuma-se designar um conjunto de trabalhos de pesquisa sociológica realizados no período compreendido entre 1925 e 1940, por professores e estudantes da universidade em Chicago. [...] Nem sempre se trata, é claro, de uma corrente de pensamento homogênea, com uma abordagem teórica comum, mas, apesar disso a Escola de Chicago apresenta diversas características que sem dúvida lhe conferem uma grande unidade e lhe atribuem um lugar particular e distinto na sociologia americana".

${ }^{6}$ Um dos mais renomados sociólogos de Chicago, Park (1967, p. 12) percebia a cidade como um laboratório para a investigação da vida social. Nas suas próprias palavras "hoje, o mundo inteiro ou vive na cidade ou está a caminho da cidade; então, se estudarmos as cidades, poderemos compreender o que se passa no mundo".

${ }^{7} \mathrm{Um}$ dos mais completos e atualizados estudos sobre a Universidade de Chicago, contendo 1.221 páginas, pode ser encontrado em Boyer (2015).

${ }^{8}$ A partir da filosofia da Escola Pragmática, segundo a qual o sentido de uma ideia deve corresponder ao conjunto de seus desdobramentos práticos, entende-se que o estudo sobre as causas do crime refletirá, de maneira direta,
} 
direitos fundamentais, o que de certa forma contribui para que a sociedade exija a elaboração e realização de políticas públicas, isto é, que o conjunto de leis voltadas para a garantia dos direitos sociais seja efetivado e não se configure apenas como mera formalidade legislativa.

Nesse caminhar e partindo do entendimento segundo o qual as possibilidades e os atores relacionados ao desenvolvimento de políticas públicas acabam por se configurar como um campo deveras complexo e extenso, em razão mesmo das características dos problemas aqui apontados como gênese de comportamentos criminosos, assim como, do âmbito de competência mais próximo dos cidadãos e com maior probabilidade de eficiência e eficácia para enfretamento das violências pela via das políticas públicas não repressivas, adotamos como o espaço institucional mais apto para tal enfretamento o das municipalidades.

Assim sendo, este estudo propõe, sobretudo, uma reflexão e análise acerca da possível consequência da adoção de políticas públicas municipais de abrangência social como mecanismo na prevenção e combate da criminalidade, tendo em vista que, por meio da efetivação de instrumentos capazes de diminuir as profundas desigualdades sociais que se refletem por meio da desorganização social e urbana, em respeito mesmo aos princípios contidos no bojo da Constituição da República Brasileira, é que se poderá - também e quem sabe, principalmente -, fora do contexto reativo/repressivo, buscar soluções para a crescente onda de violências estrutural e criminal que estão a assolar o país.

Para alcance de tal desiderato, no primeiro tópico encontra-se o referencial teórico, a teoria que embasa todo o pensamento exposto no presente trabalho, no qual serão abordados os aportes teóricos desenvolvidos desde o início do século passado pela Escola Sociológica de Chicago.

Ultrapassada essa fase, no segundo item, como forma de contextualização mais específica do problema da criminalidade aqui estudado e da especialização quando da elaboração de políticas públicas para enfrentamento deste, imprescindível que averiguássemos a pertinência do que defendido pelos sociólogos de Chicago no contexto espacial das cidades brasileiras.

Desse modo, através de detalhada pesquisa bibliográfica, procedemos a atualização de tais informações pela via de estudos desenvolvidos por pesquisadores brasileiros exclusivamente voltados para o estudo da criminalidade nos Municípios que integram o Sistema Federativo do país.

Por fim e consequentemente, em sintonia a tudo quanto exposto nos itens precedentes e, seguindo a linha da filosofia pragmática, tão cara aos sociólogos aqui estudados, no terceiro e último tópico, apresentamos as possibilidades de implementação do saber até então produzido, daquilo que

no campo das políticas criminais a serem desenvolvidas, contribuindo para que as mesmas sejam pensadas de maneira mais realista e, portanto, com maiores possibilidades de alcance dos fins propostos. 
concretamente poderá ser planejado e efetivado pelo Poder Político, em estreita sintonia com a sociedade civil, no âmbito do desenvolvimento de políticas públicas que guardem absoluta proximidade com os fundamentos de um Estado Democrático de Direito.

Em busca de tal desiderato, levamos a efeito uma análise sobre a composição federativa do Brasil, com o propósito de colher subsídios sobre a melhor forma de gestão das políticas de Segurança Pública preventivas, acabando por indicar o âmbito das municipalidades como o mais profícuo para desenvolvimento de tais políticas públicas, vez que os Municípios são os órgãos federados que reúnem as melhores características, aquelas que podem ser consideradas as mais completas para o combate à violência estrutural ${ }^{9} \mathrm{e}$, consequentemente, à violência criminal.

Este o desafio do trabalho que se segue.

\section{CRIME E CIDADE: APORTES TEÓRICOS DA ESCOLA DE CHICAGO}

\subsection{Uma introdução à Sociologia da Escola de Chicago}

No âmbito do que produzido no Brasil sobre a Escola de Chicago, a maioria dos trabalhos elaborados se deram na área da sociologia, antropologia, arquitetura, psicologia e, mais recentemente, geografia, com enfoques muito variados, abordando com mais frequência a questão dos métodos de pesquisa desenvolvidos, analisando trabalhos específicos, muitas vezes até conectando desorganização social, desorganização urbana e criminalidade ${ }^{10}$ sem, contudo, desenvolver uma visão mais jurídica sobre o assunto, sem aprofundar - ou até mesmo conectar -, especificamente, com política criminal, com políticas de segurança pública ${ }^{11}$.

Não obstante tal fato, a relação entre violência e a urbanização - ou a falta dela - sempre foi tratada como uma questão instigante e, até mesmo, relevante, vez que não seria razoável ignorar que grande parte das transformações que as cidades sofreram e continuam sofrendo tem impactos

\footnotetext{
${ }^{9}$ Inicialmente desenvolvida por Baratta (1999), uma definição bem atualizada de violência estrutural e adotada no trabalho que agora se inicia, pode ser encontrada em Michalowski (2010), para quem em tal definição: "estariam presentes lesões, doença ou morte devido a formas de pobreza e desigualdade, danos no ambiente de trabalho, riscos ao consumidor, poluição ambiental, sexismo, racismo e exclusão étnica, preveníveis ou facilitadas pelo Estado, e a perda da vida, saúde, recursos econômicos e autonomia devido ao neocolonialismo, ao neoimperialismo e à globalização neoliberal".

${ }^{10} \mathrm{Um}$ trabalho acadêmico brasileiro que fez a devida conexão entre os ensinamentos da Escola de Chicago e o desenvolvimento de políticas públicas de prevenção ao crime foi desenvolvido por Tangerino (2007).

${ }^{11}$ Cfr. Massena (1986), Adorno (1990), Misse (1995), Joas (1999), Beato e Reis (2000), Siqueira (2001), Sogame (2001), Felix (2002), Freitas (2002), Teodósio (2003), Cerqueira e Lobão (2004), Ferreira e Penna (2005), Diniz (2005), Braga e Gastaldo (2009), Carvalho et al (2010), Batella e Diniz (2010), Evangelista (2012), Andrade et al (2013), Melhem (2013), Cabral de Lira (2014), Lira (2014), Delgado (2014), Casteletto (2014), Galvão (2014), Melo e Matias (2015), Ramos (2015), Faria et al (2015), Lira (2015), Santos (2016), Valentin e Pinezi (s/d).
} 
multifacetados, de muitas naturezas, que interferem de modo direto na produção da violência e do medo.

A partir de tal premissa, podemos defender a ideia segundo a qual a estrutura urbana deve ser levada em consideração como um dos determinantes do fenômeno da violência e do crime, devendo-se mesmo ter em conta o intenso processo de produção e transformação do espaço e da reprodução social que caracteriza a permanente mutação de determinados setores das cidades.

Como consequência direta da adoção de tal entendimento, temos uma facilitação no alcance dos resultados projetados para as políticas a serem desenvolvidas no âmbito do controle social, vez que ao delimitar-se um campo específico de atuação, com um planejamento orientado para o enfrentamento de determinado problema - aqui a desorganização social e urbana -, maiores são as chances de avanços na esfera do disciplinamento da sociedade.

Importante, dessa forma, levar-se a efeito uma tessitura teórica que faça as devidas conexões de ideias entre o papel desempenhado pelas cidades no âmbito da violência criminal como reflexo da violência estrutural que permeia determinados espaços urbanos, aprofundando a pesquisa especificamente nos níveis de influência que a desorganização social e urbana representam nesse contexto vez que, reconhecemos, não são os únicos determinantes dos comportamentos delituosos.

Essa a razão de, no presente capítulo, mais do que em autores, ou seja, nos conhecidos sociólogos da Escola de Chicago, tencionarmos fazer uma exposição das ideias destes, inclusive de forma diacrônica ${ }^{12}$, para que melhor possamos dar uma linearidade teórica que se amolde aos fins aqui pretendidos, quais sejam: orientações para elaboração de políticas criminais ${ }^{13}$.

Assim sendo, ao invés de conectar temáticas, trabalhos e conceitos a determinados autores, o que já feito de forma exaustiva pela academia, optamos por descrever de forma detalhada o desenvolvimento das ideias ali produzidas, mormente as que defendem ser íntimas as relações entre desorganização social e desorganização urbana e entre estas e o cometimento de delitos ${ }^{14}$, com o claro propósito de aprofundar tais possibilidades teóricas com a realidade das cidades brasileiras e, caso possível, conectá-las com políticas criminais que possam informar políticas públicas de segurança ${ }^{15}$.

\footnotetext{
${ }^{12}$ Sobre o desenvolvimento da Escola de Chicago, cronologicamente, cfr. Becker (1996).

${ }^{13}$ Alguns textos introdutórios ao pensamento produzido ne Escola de Chicago podem ser encontrados em Newburn (2009).

${ }^{14}$ Desde já, e com o intuito de evitar críticas desnecessárias, parte-se do entendimento de que nenhum fator isolado pode explicar por que alguns indivíduos se comportam com violência em relação a outras pessoas, cometendo crimes, assim como, pode explicar as razões pelas quais a criminalidade é mais acentuada em algumas comunidades e não em outras. Filiamo-nos ao entendimento que percebe o fenômeno criminal como uma combinação de fatores que podem indicar a emergência de condutas delituosas em diferentes níveis, locais e tipologias.

${ }^{15}$ Imprescindível, desde logo, chamar a atenção para o fato de que os postulados da sociologia desenvolvida na Universidade de Chicago ainda hoje causam grande controvérsia, existindo vários trabalhos acadêmicos que discordam total ou parcialmente dos fundamentos teóricos que associam desorganização social com
} 
Nesse caminhar iniciaremos a abordagem a partir da primeira fase da escola de Chicago, que marca o nascimento da sociologia urbana, na qual é priorizada a discussão acerca da conformação urbana como elemento central da desorganização social de comunidades e espaços urbanos, ou seja, a partir da análise da estruturação das cidades, buscava-se a compreensão sobre o impacto que o desenvolvimento urbano sob o efeito da crescente industrialização produziria nas esferas social, econômica e política.

Dessa forma, a partir do entendimento segundo o qual as paulatinas transformações pelas quais todas as cidades passam em seus ciclos de desenvolvimento acabam por apresentar impactos variados, mormente na produção da violência e, consequentemente, do medo, necessário se fazia aprofundar a pesquisa sobre a estrutura urbana das cidades para que se pudesse identificar os determinantes de tais fenômenos.

Nessa fase de desenvolvimento teórico se sobressaíram os estudos de Wirth (1979), cuja preocupação epistemológica era uma constante, tendo este sociólogo envidado esforços para elaborar os conceitos básicos que permitissem o desenvolvimento de uma sociologia das cidades e, desde então, baseando suas pesquisas no recorte temático segundo o qual a cidade era um local em que as relações sociais se encontravam fragmentadas, anônimas e superficiais, originando sentimentos de insegurança e situações de conflito social tendo, em tal contexto, os mecanismos de controle social formal adquirido relevância acentuada. ${ }^{16}$

Essa preocupação metodológica parece ser uma constante nos trabalhos desenvolvidos em tal contexto acadêmico, sendo imperioso que seja abordada, logo no início deste capítulo, a questão do método utilizado pelos pesquisadores da Universidade de Chicago para chegar a resultados confiáveis que comprovassem as teorias que, então, estavam a ser desenvolvidas.

Desta feita, necessário se faz chamar a atenção para a questão do intenso pragmatismo que permeia tudo o que produzido por tal sociologia. Muitos dos professores de Chicago, como muitos dos primeiros sociólogos americanos, eram pastores protestantes profundamente comprometidos com

desorganização urbana e estas com o cometimento de delitos. Cfr. Coelho (1980), Coelho (1988), Paixão (1990), Caldeira (2000), Castells (2000), Andrade (2003a), Cerqueira e Lobão (2004), Diniz (2005), Silva e Marinho (2014). A síntese de tal controvérsia pode ser resumida pela seguinte proposição de Beato Filho (2012, p. 86): “Creditase a nossa enorme dívida social a origem dos graves problemas de criminalidade e violência que o país enfrenta. Vivemos em um dos cinco países mais violentos do mundo, e as razões disso são de ordem socioeconômica, sendo concentradas no plano macroestrutural. Trata-se de um argumento fácil de enunciar, mas extremamente difícil de provar."

${ }^{16}$ Em um de seus mais conhecidos trabalhos, intitulado "Urbanismo como forma de vida"”, Wirth (1979, p. 113) em suas conclusões afirma que "Para finalidades sociológicas, uma cidade é uma fixação relativamente grande, densa e permanente de indivíduos heterogêneos. Os grandes números são responsáveis pela variabilidade individual, pela relativa ausência de conhecimento pessoal íntimo, pela segmentação das relações humanas as quais são em grande parte anônimas, superficiais e transitórias e por características correlatas". 
reformas sociais, cujo interesse seria produzir saberes, portanto, voltados para o equacionamento dos problemas sociais que afligiam as grandes cidades americanas.

Assim sendo, à época, no Departamento de Sociologia da Universidade de Chicago, todos comungavam da posição de que algo precisava ser feito para enfrentar os graves problemas que afligiam a sociedade estadunidense, mormente aqueles ligados à pobreza ${ }^{17}$.

Deste modo, o empirismo que acaba por caracterizar a filosofia pragmática adotada pelos sociólogos em Chicago, é marcado pela insistência de tais pesquisadores em produzir conhecimento que pudesse ser útil, tivesse aplicabilidade prática em prol do enfrentamento das dificuldades inerentes à estrutura social de então. (NASCIMENTO, 2010)

Portanto, em razão de adoção de tal filosofia pragmática (DEWEY, 2018) os estudos em Chicago acabam por se voltar para a temática urbana e para o trabalho de campo. Nesse sentido, a Escola de Chicago se distancia da até então em voga sociologia especulativa, inaugurando o que viria a ser conhecida como uma sociologia da ação, de viés humanista, fortemente impregnada de valores religiosos e comprometida com a transformação social ${ }^{18}$.

Para alcance dos objetivos acima delineados, necessário que se desenvolvessem métodos de pesquisa aptos a auxiliar em tal mister.

Neste ponto várias foram as inovações produzidas, sendo tributárias em maior ou menor medida, do desenvolvimento teórico denominado de interacionismo simbólico (MEAD, 1934), ou seja, a partir da perspectiva do proposto pelo interacionismo simbólico, enquanto referencial ou base teórica, novas metodologias de pesquisa passaram a ser desenvolvidas, ocorrendo uma verdadeira revolução na estrutura método. (FELGUEIRAS, 2016)

Em apertada síntese, para os interacionistas, todo e qualquer método a ser desenvolvido deveria partir do ponto de vista dos agentes sociais, elucidando as significações que estes próprios põem em prática para construir seu mundo social ${ }^{19}$. Nas palavras de Coulon (1995, p. 22), “É preciso preservar a integridade do mundo social para poder estudá-lo, e levar em conta o ponto de vista dos agentes sociais, pois é através do sentido que atribuem a objetos, indivíduos e símbolos que os rodeiam, que eles fabricam seu mundo social".

\footnotetext{
${ }^{17}$ Importante pontuar a advertência elaborada por Joas (1999), para quem um dos grandes equívocos a respeito da Escola de Chicago foi concebê-la como unicamente interessada em promover reformas sociais e acreditar que sua natureza específica consistia num reformismo social protestante secularizado. Chama a atenção para o fato de que mesmo nos textos recentes de autores de "primeira linha", como Tenbruck, Vidich e Lyman essa interpretação equivocada pode ser encontrada.

${ }^{18}$ Sobre o assunto, por todos, Coulon (1995).

${ }^{19}$ Em conhecido artigo, Abbott (1997, p. 1154, tradução livre) explana que: "Os escritores de Chicago acreditavam na estrutura social como um conjunto de estabilidades temporárias em um processo de fluxo e determinação recíproca. 0 mundo social era composto de atores que determinavam mutuamente uns aos outros de maneiras às vezes deliberadas e por vezes bastante imprevistas".
} 
Em tal linha de pensamento, e este o ponto que mais interessa para avanço nas pesquisas comportamentais e, portanto, criminológicas, entendem os interacionistas que é a partir das interpretações do mundo que os rodeia, dos significados que provém das relações interativas dos agentes sociais - relações de vizinhança, de trabalho, com o meio físico, ambiental, urbano, etc... que os agentes determinam as suas condutas ${ }^{20}$.

Assim pensando, enfrentaram o que talvez seja a questão mais básica da responsabilização individual do homem pelos seus atos, que remonta ao histórico embate teórico entre as Escolas Clássica e Positiva do Direito Penal (GUIMARÃES, 2013), o velho dilema entre o voluntarismo e o determinismo das condutas, ou seja, refutaram o caráter determinista e involuntário da conduta humana, como queria Lombroso, e afirmaram que o homem tem liberdade de escolha para adoção de comportamentos ${ }^{21}$.

Tal entendimento pode ser considerado como um divisor de águas na área da Criminologia, vez que contribuiu de forma substancial para a discussão acerca dos fatores que desencadeiam a conduta desviante, ultrapassando em definitivo a era do determinismo delinquencial imanente ao próprio criminoso como explicação exclusiva de tal fenômeno social.

Portanto, da junção de ideias oriundas da filosofia pragmática, enquanto filosofia da ação, com as ideias produzidas no âmbito do interacionismo simbólico, restou que os sociólogos de Chicago, por via óbvia, privilegiaram o trabalho da pesquisa de campo, como forma de melhor conhecer a cidade e seus moradores e, por este caminho metodológico, apresentar soluções para resolução dos problemas ali localizados.

Dessa forma, sem desconsiderar o método estatístico, base das pesquisas quantitativas, a sociologia de Chicago, de forma geral, se orientava no sentido de que somente números, estudos estatísticos do comportamento das populações, não poderiam fornecer base para uma análise aprofundada do fenômeno estudado quando não acompanhados da história de vida dos indivíduos. Entendiam ser necessário, nas pesquisas, assumir o papel do agente, analisar o mundo do ponto de vista deste, abrindo mão da objetividade representada pela observação distanciada, exterior. (THOMAS E ZNANIECKI, 1927)

\footnotetext{
${ }^{20}$ Maior aprofundamento em Blumer (1986).

${ }^{21} \mathrm{Na}$ perspectiva de Felgueiras (2016, p. 143): “Conforme referimos, a abordagem interacionista critica a abordagem determinista, defendendo uma perspectiva construtivista, o que significa que o ser humano constrói o seu comportamento, a partir de um processo de interpretação, escolhe a conduta a adotar. Assim sendo, o ser humano não reage mecanicamente aos estímulos exteriores, existindo um processo elaborado de interpretação, que poderá ou não refletir anteriores acontecimentos ou experiência do indivíduo. A conduta humana, no fundo, é uma construção imprevisível que resulta do pensamento do ser humano e/ou interação com os outros. Em certa medida, o Homem enquanto ser criador tem a capacidade de influenciar o traçado de seu próprio destino".
} 
Em razão de tal ponto de vista, as pesquisas se voltaram para cartas pessoais, o histórico de vida, a entrevista, a observação, relatórios de assistentes sociais, autos forenses, enfim, tudo que pudesse colaborar para o entendimento do fenômeno estudado sob a perspectiva dos indivíduos ${ }^{22}, \mathrm{o}$ que levou, em última instância, ao que ficou conhecido como observação participativa, na qual o investigador ficava completamente imerso em seu campo de estudos, assumindo um papel de tempo integral na comunidade estudada ${ }^{23}$.

Em síntese, profunda é a divergência teórica acerca do método, metodologia e validade dos resultados produzidos pelos sociólogos da Escola de Chicago nos seus primórdios, entretanto, a multiplicidade metodológica empírica lá desenvolvida originalmente, representou um grande avanço no campo investigativo acadêmico, com uma profunda contribuição para as pesquisas etnográficas no sentido de descrever e, assim, revelar as normas de comportamento, os costumes, crenças e tradições de uma sociedade -, cujo maior contributo foi ultrapassar as fronteiras de uma sociologia especulativa, até então em voga.

\subsection{Das interconexões entre desorganização social, desorganização urbana e criminalidade}

Do até agora exposto, tendo sido resgatados os cânones gerais nos quais se fundamentavam a sociologia desenvolvida na cidade de Chicago desde os idos do início do século XX, já é possível explicitar o entendimento de seus sociólogos acerca da conduta humana, mormente a criminosa ${ }^{24}$.

Para tanto, necessário que ratifiquemos o papel central do estudo das cidades, enquanto aglomerações urbanas 'organizadas', vez que é através de tais estudos que se torna possível o estudo da criminalidade sob a perspectiva de uma espacialidade determinada, ou seja, entendiam os

\footnotetext{
${ }^{22}$ Sutherland (1937) aprofunda tal metodologia, ultrapassando os limites do sujeito empírico para alcançar a perspectiva do sujeito analítico, ou seja, ao estudar os ladrões profissionais, além dos relatos de suas histórias de vida, utilizou a interpretação que os mesmos faziam destas.

${ }^{23}$ Sobre as diversas posições dos principais sociólogos de Chicago em relação à questão metodológica, em detalhes, Coulon (1995, p. 99), para quem "Escolher um método é escolher uma teoria. Como nenhuma metodologia se justifica por si mesma, para compreender essa escolha e o seu uso, é preciso aproximá-la da teoria com a qual é compatível e até mesmo que ela por vezes representa".

${ }^{24}$ Algumas críticas foram feitas aos estudos realizados pelos sociólogos de Chicago, no que pertine a explicação da conduta criminosa, alegando que tais estudos somente alcançavam determinados tipos de crimes, não explicando, por exemplo, a criminalidade de colarinho branco. Críticas, no nosso entendimento, insustentáveis, haja vista que em nenhum trabalho da Escola de Chicago existe qualquer menção a explicar a totalidade de motivos que levam uma pessoa a cometer delitos, sendo seus sociólogos bem claros em delimitar o objeto de seus estudos à criminalidade ligada às questões de desorganização social e urbana, assim como, apresentando sugestões de combate a mesma, somente em tal seara. Para acesso a tais críticas, de forma direta ou indireta, cfr. autores ligados à Criminologia Crítica, como Santos (1984), Batista (1990), Zaffaroni (1991), Melossi (1992), Zaffaroni (1997), Pavarini (1998), Baratta (1999), Andrade (2003b), Bergalli (2003), dentre outros.
} 
sociólogos de Chicago ser possível a identificação de áreas com maior propensão para a prática de determinados tipos de delitos ${ }^{25}$.

Logo, é a partir dos estudos baseados no desenvolvimento da sociologia urbana, caracterizada pelo aprofundamento da discussão sobre a conformação urbana como elemento central da desorganização social de comunidades e espaços urbanos, que foram buscadas as explicações para a compreensão das interrelações entre desorganização social, desorganização urbana e criminalidade ${ }^{26}$.

Em tal perspectiva é importante que se resgate o conceito de ecologia humana, por se tratar de um conceito imprescindível para o entendimento das ligações entre crime e cidade.

Pois bem, por ecologia humana deve-se entender o estudo dos seres vivos como membros de uma complexa rede de organismos conexos, que interagem entre si. Como derivações de tal conceito, inicialmente foram elaborados outros dois conceitos: o da dominância, que seria a disputa pelas áreas da cidade de maior valor e o da sucessão que seria uma modificação cíclica nas áreas de povoamento em razão do valor dos imóveis lá localizados. (PARK E MCKENZIE, 1984)

Posteriormente, ainda no âmbito da ecologia humana, foi introduzido o conceito da competição que ampliou o conceito de dominância, indicando que além da competição definir a ocupação dos melhores locais da cidade, definirá, também, a posição do indivíduo na comunidade, ou seja, é pela dominância, competição e sucessão que se dá o processo pelo qual a organização distributiva e ecológica da cidade é criada. (PARK E BURGESS, 1921).

Por fim, para explicar de modo mais completo o fenômeno da expansão territorial e da consequente distribuição populacional, denominado pelos autores acima referidos como ciclo ecológico, foram definidos cinco estágios, iniciando-se com a invasão, que seria a entrada das populações migrantes nas áreas antigas e centrais da cidade, seguido pela sucessão caracterizada pela mobilidade residencial das populações para áreas mais periféricas, sucedido pela seleção, no qual a localização residencial é definida por critérios ecológicos, como língua, etnia e renda, dentre outros, prosseguido pelo estágio da segregação, que atua de forma complementar à seleção, com maior ênfase no papel da cultura local para determinação da localização dos grupos sociais e, por fim, o da acomodação, no qual se dá o equilíbrio e a consolidação de áreas sob dominância de determinado grupo social ${ }^{27}$.

Vários foram os trabalhos desenvolvidos a partir de tal arcabouço teórico, sendo um dos mais conhecidos aquele que dividiu a cidade em círculos concêntricos, cujo objetivo foi determinar a divisão

\footnotetext{
${ }^{25}$ Hodiernamente, tal perspectiva é amplamente utilizada, existindo até mesmo um software denominado RTM - Risk Terrain Model, que se propõem a fazer análise de risco de cometimento de delitos baseado em dados levantados em determinados locais. Maiores detalhes em Caplan (2016).

${ }^{26}$ Maior aprofundamento em Wirth (1979).

${ }^{27}$ Um trabalho específico sobre Ecologia Humana pode ser encontrado em Eufrásio (2013).
} 
espacial da cidade para que melhor se pudesse estudar os fenômenos sociais em cada um desses campos delimitados. (BURGESS, 1970)

Cinco seriam as zonas concêntricas que estabeleceriam a aplicação da ecologia humana às cidades: zona I, o centro comercial e de negócios; zona II, chamada zona de transição; zona III, a dos bairros operários; zona IV, a residencial de classes médias e elevadas; e zona $\mathrm{V}$, das pessoas que vivem próximos das áreas rurais, mas trabalham na cidade.

Desta feita, estabelecidos os espaços da cidade através dos fenômenos da dominância, competição e sucessão, complementados posteriormente pelos fenômenos da invasão, seleção, segregação e acomodação, observaram os pesquisadores que em determinados locais, com características bem delineadas, havia uma nítida propensão para o cometimento de delitos. Ademais, foi detectado que nesses locais se encontrava o tecido social mais desgastado, com uma profunda desorganização social e controle social praticamente inexistente. (THOMAS E ZNANIECKI. 1927).

Analisando-se os fenômenos acima descritos sob a perspectiva da atualidade destes, percebemos serem necessárias algumas correções, posto que já não há nas cidades, mormente nas megalópoles, uma divisão clara como a apontada nos círculos concêntricos.

Por outro lado, sem a pretensão de aprofundamento, necessário que se ressalte a procedência de algumas críticas, como a formulada para explicar que a segregação espacial não ocorre unicamente por critérios de ecologia humana.

Podemos afirmar ser ainda comum nos dias de hoje a atribuição de determinado status à pessoa em razão do endereço no qual habita, sendo claramente refletido tal fenômeno por meio da especulação imobiliária, no qual determinadas áreas da cidade são mais ou menos valorizadas em razão de seu entorno, sendo fator preponderante nesse cálculo a vizinhança que lá habita ${ }^{28}$.

Entretanto, neste ponto, temos que concordar com a crítica de Castells (2000), fundamentada na Teoria Marxista, que aponta a omissão da sociologia de Chicago em relação à análise das relações entre as classes sociais, a partir da perspectiva da dominação econômica e política, relações estas que estariam diretamente conectadas à apropriação do espaço urbano.

A conformação urbana, assim, não seria um processo natural, como defendido por Park e Burgess (1921) e sim a consequência direta de interesses segmentados. Para o paradigma marxista, em síntese, longe de ser um processo que se explica somente pelos conceitos de dominância,

\footnotetext{
${ }^{28}$ No Brasil é fato incontestável a desvalorização das áreas próximas às favelas, em razão destas apresentarem alto índice de desorganização social e urbana e, consequentemente, altos índices de violência criminal o que, consequentemente, leva a estigmatização de seus moradores, principalmente em sede de controle social formal, desencadeando o conhecido processo de seletividade. Sobre tal fenômeno, por todos, Baratta (1999).
} 
competição e sucessão, a segregação espacial é produzida por conflitos sociais, políticos e econômicos entre os grupos que compõem o corpo social.

Aponta a crítica, de forma veemente, que não há preocupação da Escola de Chicago em explicar as causas da imigração, por exemplo, que sob a ótica marxista está diretamente ligada a questões das lutas sociais pela hegemonia política e econômica ${ }^{29}$.

Independentemente da determinação das causas do recorte espacial das cidades, das origens da configuração deste - a realidade atual aponta para a existência da segregação de determinados estratos sociais em determinadas áreas, chegando-se à conclusão de que o status econômico é intrínseco ou imanente a tal determinação -, o que interessou a sociologia de Chicago foi o aprofundamento da pesquisa sobre quais as consequências que adviriam das profundas diferenças sociais existentes entre os moradores das áreas que compunham a referida configuração urbana. (THOMAS, 1923)

Nessa senda, a desorganização social, nos estudos realizados pelos sociólogos de Chicago, configura-se como um fator preponderante nas áreas habitadas por pessoas de menor poder econômico e está diretamente conectado com o cometimento de delitos. Tal desorganização social tem origem na desagregação da família, que tem impacto direto na desagregação comunitária ${ }^{30}$.

Assim sendo, sem que a família e a comunidade possam exercer um fundamental papel no controle social, de base ética e moral, sem que possam impor, deste modo, aos seus membros um conjunto de regras comum, tem-se, consequentemente, um impacto considerável nos índices de criminalidade.

Em síntese, com o desenvolvimento urbano das cidades as camadas mais pobres ${ }^{31}$ da população foram sendo empurradas para a periferia, onde a urbanização era - e continua sendo precária, configurando-se como áreas deterioradas, com infraestrutura absolutamente precária, tendo tal deslocamento causado a ruptura de seus laços familiares e comunitários ${ }^{32}$, dificultando o controle

\footnotetext{
${ }^{29}$ Silva e Marinho (2014, p. 27) advertem que: "Assim, vários autores marxistas têm questionado a relevância da sociologia urbana. Para estes, os fenômenos que afetam a distribuição das vizinhanças estão ligados a características gerais das sociedades capitalistas e, ao mesmo tempo, lhe conferem uma dimensão especial. Dessa forma, a análise da distribuição das vizinhanças urbanas é localizada nas lutas de grupos nos mercados residenciais que se dá de forma interdependente com fenômenos centrais das sociedades capitalistas, como a expansão dos mercados de trabalho, de capital industrial e financeiro".

${ }^{30} \mathrm{Um}$ aprofundado estudo crítico sobre o conceito de desorganização social formulado pela sociologia de Chicago - de leitura imprescindível - pode ser encontrado em Bursik Jr. (1988).

${ }^{31} \mathrm{Em}$ tal seara, importante a observação feita por Tangerino (2007, p. 70), para quem: "Assim como seriam inadmissíveis relações diretas entre etnia e crime, também assim as relações de pobreza e crime. Entretanto, estar submetido a uma situação de pobreza é um componente ecologicamente relevante, pois serão os mais pobres a se verem obrigados a residir nas piores regiões, onde residem os autores das infrações criminais. Sobre as relações entre pobreza e criminalidade, em maiores detalhes, Ferreira e Penna (2005).

32 A movimentação populacional intensa entre as diversas áreas da cidade, causada pelos fenômenos da dominância, sucessão e competição, rompe o contato e os laços entre os componentes de determinada
} 
social informal, estabelecendo-se, assim, a somatória destas características como um profícuo caldo de cultura para o cometimento de crimes, mormente contra a pessoa, patrimoniais e de tráfico de drogas.

Vê-se, pois, em tal perspectiva teórica que o espaço urbano adequado, ou seja, aquele que se amolda aos requisitos de um local habitável sob a perspectiva da cidade moderna, acaba por ser uma peça chave na questão da sociabilidade e, consequentemente, do controle social, na medida em que ele funciona como um importante elemento estabilizador e regulador que vem a reforçar os sentimentos de pertencimento ao meio local, favorecendo a estabilização de relações sociais pacíficas.

Aliado à importância do que até agora exposto, ou seja, a viragem metodológica para pesquisa da conduta humana, assim como a mudança de perspectiva para explicação da prática de atos criminosos, deve ser atribuída a Escola de Chicago o mérito de apresentar outros meios, outras políticas para o combate da criminalidade ${ }^{33}$.

Sem questionar ou atacar os meios de controle social formal e sem preocupações em dar aos estudos desenvolvidos um status de exaurimento na explicação do fenômeno criminal, a sociologia de Chicago desenvolveu, de forma clara, pesquisas na área da violência urbana, indicando de forma precisa caminhos a serem seguidos para enfrentamento desta.

Nesse ponto, talvez resida a maior importância de suas pesquisas e produção científica, vez que ao detectarem/denunciarem as péssimas condições de vida de determinada parcela da população como uma das causas da criminalidade, apontaram como solução não opções repressivas, mas sim políticas públicas de inclusão social, pela via de recuperação urbana das áreas degradadas, assim como de medidas que combatessem a pobreza, a exclusão social, a falta de educação, enfim, que proporcionassem melhores meios de convivência para toda a população ${ }^{34}$.

comunidade e, até mesmo, laços familiares, enfraquecendo sobremaneira a possibilidade do controle comunitário e familiar sobre o indivíduo, tendo como consequência propiciar maiores índices de criminalidade na área invadida. Sobre o tema, em profundidade, Shaw e McKay (1942).

${ }^{33}$ Sobre a atualidade de tal perspectiva, cfr. Evangelista (2012).

${ }^{34}$ Sobre o tema, imprescindível conhecer o Chicago Area Project - CAP (2018, tradução livre), que "foi fundado na década de 1930 por Clifford Shaw, um sociólogo da Universidade de Chicago, que acreditava que cada bairro poderia reduzir a delinquência juvenil melhorando a vida comunitária. Nossa missão original não mudou desde essa fundação. A longa história de construção da comunidade da CAP demonstrou que os residentes de baixa renda são tão capazes quanto outros em abordar questões críticas do bairro. CAP acredita que os problemas da comunidade não podem ser resolvidos trazendo agências externas para "consertar" problemas locais, como delinquência, violência de gangues, abuso de substâncias entorpecentes e desemprego. Chicago Area Project é uma rede forte com mais de 40 organizações de base e projetos especiais destinados a promover o desenvolvimento positivo da juventude e prevenir a delinquência juvenil através da construção de comunidades. Iniciado em 1934, a CAP baseia-se no conceito de que cada bairro tem os líderes que precisa para resolver seus próprios problemas". 


\section{ESPAÇOS URBANOS, VIOLÊNCIA ESTRUTURAL E VIOLÊNCIA CRIMINAL NO BRASIL. PERTINÊNCIA TEÓRICA DA SOCIOLOGIA DE CHICAGO?}

No presente tópico, baseados nos estudos desenvolvidos por sociólogos, geógrafos e criminólogos brasileiros ${ }^{35}$ - por terem uma maior aproximação ao problema da violência no Brasil -, e que adotaram como referência teórica o que produzido pela Escola de Chicago, empreenderemos uma revisão sobre trabalhos que enfrentaram de forma específica as questões inter-relacionadas na esfera da desorganização social, desorganização urbana e criminalidade, com o intuito de averiguar a plausibilidade teórica, os indicativos sobre as aproximações entre tais fenômenos sociais.

Importante destacar que os recursos metodológicos eleitos - exclusivamente a revisão bibliográfica - para a investigação que agora passamos a apresentar, apenas permitiram a busca de indicativos, de plausibilidade teórica, de razoabilidade ou pertinência dos argumentos apresentados outrora pela Escola de Chicago, hoje também estudados pelo que se denomina de Geografia do Crime $^{36}$, ou seja, de que a partir das características, mormente as sociais e urbanas, de determinadas áreas é possível identificar uma maior propensão para o cometimento de determinados delitos, sem nenhuma pretensão de comprovação definitiva de tal fenômeno.

O posicionamento acima esposado se deve ao fato de que é bastante recorrente nos estudos desenvolvidos na área da Segurança Pública no Brasil o entendimento que indica a falta de dados confiáveis ${ }^{37}$, assim como, um absoluto déficit de bases sólidas e científicas que venham a propiciar informações confiáveis para enfrentamento do problema da violência, chegando-se mesmo a afirmar que "esta não é propriamente uma área de conhecimento, mas um terreno baldio, onde proliferam suposições, preconceitos, senso comum, magia e palpites mais ou menos bem intencionados". (BEATO FILHO, 2012)

\footnotetext{
35 Por via transversal, para os fins aqui propostos, a Criminologia Crítica brasileira, acaba contribuindo para a compreensão do fenômeno criminal, ao desconstruir as formas tradicionais de análise do crime e da criminalidade, o que pode ser sintetizado no pensamento de Andrade (2003), para quem "houve uma mudança de pensamento, uma verdadeira quebra de barreira estudada nas Ciências Sociais e na Criminologia Crítica, que possibilitam a desconstrução e a superação do senso comum de criminalidade, da cidadania e da violência, possibilitando novas visões e novos discursos". Sobre uma nova perspectiva de análise do crime e da criminalidade, por todos, Baratta (1999).

${ }^{36}$ Uma das primeiras obras publicadas no Brasil especificamente sobre a temática foi Felix (2002), para quem por Geografia do crime pode-se entender "o estudo do crime a partir de uma ótica da dinâmica demográfica e espacial", assim sendo, "A Escola Geográfica do Crime, principalmente a partir do início da década de 1970, tem buscado, à luz de teorizações diversas e através de análises associativas com outros campos científicos, elucidar os processos que levam ao problema. Se o crime é um fenômeno social que reflete certas condições de vida, diferenciadas por situações socioeconômicas, culturais, políticas, demográficas, espaciais, etc., é o estudo destas condições que levará à compreensão dos níveis de variação da violência".

${ }^{37}$ Nesse sentido o fenômeno vem de longa data. Cfr. Adorno (2002), Cerqueira e Lobão (2004), Kahn (2005), Caldeira (2000), Beato Filho (2012),
} 
Não obstante as ponderações acima expostas, tem-se percebido um notável aumento nos estudos que se preocupam com tal área de investigação no Brasil, existindo hoje uma considerável bibliografia direcionada as pesquisas no campo da Segurança Pública sob a ótica da Geografia do Crime ${ }^{38}$.

Em suma, o problema que agora passa-se a investigar, pode ser traduzido como uma mixórdia de pobreza, desemprego, violência física, baixas taxas de educação formal, tráfico de drogas, violência das gangs, proliferação de doenças, desassistência infantil, dentre tantas outras tragédias, que têm florescido nas aglomerações urbanas brasileiras, amalgamando-se em crescente violência estrutural e criminal $^{39}$, surgindo, assim, a necessidade de compreensão e explicação desse fenômeno, ou seja, necessário que se investigue quais as influências recíprocas e/ou inter-relações entre a violência e a configuração dos espações urbanos - principalmente sob o enfoque social e urbanístico -, com vistas a reestruturação deste em combate àquela ${ }^{40}$.

Isto posto e a partir de tal perspectiva, há indicativos de que nos países menos desenvolvidos, de maneira mais acentuada, as populações rurais estão em constante processos migratórios para áreas urbanas $^{41}$. A transferência da população do campo para as cidades é decorrente de vários fatores, entretanto, prepondera a busca por melhores empregos, acesso à educação, saúde, locomoção, enfim, melhor qualidade de vida a ser proporcionada por cidades mais desenvolvidas ${ }^{42}$.

\footnotetext{
${ }^{38}$ Muitos estudos foram realizados no Brasil com o objetivo de averiguar as relações entre pobreza, desigualdade econômica, desigualdade social e crime. Na década de 1990 e 2000, ainda havia muita refutação a tal relação, entretanto, estudos mais recentes vêm demonstrando, com cada vez mais frequência, que há uma estreita relação entre tais fenômenos. Para maiores detalhes, cfr. Beato Filho e Reis (2000), Cárdia e Schiffer (2000), Adorno (2002), Felix (2002), Cerqueira e Lobão (2004), Diniz (2005), Kleinschmitt et al (2011), Andrade et al (2013), Casteletto (2014), Lira (2014), Melo e Matias (2015), Lira (2015), Santos (2016), Waiselfisz (2016), Ribeiro e Cano (2016).

${ }^{39}$ Guimarães (2007), a partir dos postulados da Criminologia Crítica, apresenta um aprofundado estudo sobre as inter-relações entre violência criminal e violência estrutural, concluindo que as profundas diferenças socioeconômicas existentes entre as diversas camadas que compõem o corpo social e que, em última instância, acabam por configurar a exclusão social de significativa parcela da população (violência estrutural), tem relação direta com o cometimento de crimes (violência criminal). Há, portanto, nesse ponto específico, um compartilhamento teórico entre a Escola de Chicago e a Criminologia Crítica.

40 Para Beato Filho (2012): A escola sociológica de Chicago transfere o foco de uma análise individual de cometimento de crimes para fatores de ordem ambiental e situacional. Portanto, a estrutura física, as atividades comuns na cidade, o acesso a armas e à saúde são fatores mais imediatos de um ambiente físico e social que tendem a afetar as taxas de criminalidade. Sobre o tema, cfr., também, Oliveira (1987).

${ }^{41}$ Neste ponto, necessário diferenciar o processo de urbanização, que ocorre quando há uma conversão da população rural em urbana, pela via do êxodo rural, ou seja, a população migra da zona rural para a zona urbana, do processo de crescimento urbano, que se dá sem que necessariamente haja um processo de urbanização, ou seja, o crescimento urbano é o crescimento da própria cidade. No crescimento urbano é a cidade, a zona urbana, o espaço urbano que cresce, por meio do aumento da população. Sobre o tema, em maior profundidade, Vesentini (1994).

${ }^{42}$ Importante frisar que, hodiernamente, paralelamente ao fenômeno migratório interno, especificamente no Brasil, já está a se densificar a migração de estrangeiros por problemas humanitários ou políticos, como nos casos recentes de Haitianos e Venezuelanos.
} 
É fácil constatar que as cidades brasileiras, com destaque para as situadas na região Nordeste do País, de maneira geral, não estão preparadas para receber de forma constante e cada vez mais acelerada todo esse contingente migratório.

Torna-se impossível, assim, abrigar em condições razoáveis toda essa população que migra em elevado número, provocando o chamado inchaço urbano, contribuindo para a proliferação das favelas e gerando um problema social de difícil resolução para o Poder Público. (SARAIVA, 1989)

Consequentemente, tais cidades para acomodarem os novos habitantes acabam por se expandir através de espaços não planejados, do ponto de vista da urbanização, que são chamados de áreas naturais ${ }^{43}$ e se caracterizam por grandes extensões territoriais onde habitam pessoas sem percepções ou vínculos comunitários e ligadas por poucos elementos culturais em comum.

Essas grandes transformações sociais estariam, assim, por enfraquecer o controle social informal realizado pela família, pela vizinhança, pelas relações de trabalho, pela escola, pela igreja, entre tantas outras instituições de controle não vinculadas ao Estado, que não mais conseguiriam evitar razoavelmente o cometimento de crimes. Em suma, a diminuição dos vínculos afetivos que existiam em pequenas cidades estariam a se configurar como um fator potencializador do aumento da criminalidade. (SCHECAIRA, 2012)

Felix (2002) é taxativa ao apontar que o saldo migratório está significativamente relacionado ao crime contra o patrimônio, vez que o migrante não possui laços afetivos com o local de sua moradia e nem com a vizinhança, somado ao fato das privações sociais objetivas e baixo poder aquisitivo e de instrução, culminando com o alto índice de desemprego.

Diniz (2005) pesquisando de maneira específica a questão ${ }^{44}$, desenvolveu estudos no Estado de Minas Gerais, objetivando encontrar correlações, a partir dos postulados da abordagem da

\footnotetext{
${ }^{43} \mathrm{Em}$ uma perspectiva da Ecologia Urbana, áreas naturais são espaços homogéneos, não planificados, cuja ocupação natural e seletiva deriva da diferença entre os grupos sociais. É possível que com o passar do tempo e, necessariamente através de uma maior integração e ascensão social, aqueles que por efeito das migrações, inicialmente, se situaram num espaço marginal e de segregação, à medida que se vão integrando na comunidade, tenderão a ocupar espaços mais nobres na cidade. Por todos, cfr. Burgess (1970).

${ }^{44} \mathrm{Em}$ tal perspectiva, Diniz (2005): "Apesar da importância do fenômeno, as causas específicas e os fatores correlatos à violência urbana são nebulosos e conflitantes, uma vez que operam em dimensões distintas, variando de um indivíduo a sociedades inteiras. São inúmeras as hipóteses e construções teóricas que versam sobre os determinantes da violência urbana, mas uma, em especial, nos chama a atenção: aquela que associa a incidência criminal urbana a formas diversas de desorganização e falta de coesão social. Esta abordagem parte do princípio de que a criminalidade emerge como consequência de problemas associados a mecanismos de controle social. Neste contexto, as comunidades locais, marcadas por um complexo sistema de associações formais e informais, de relações de amizade e parentesco, contribuem para o processo de socialização e aculturação do indivíduo. Portanto, elementos que promovam a ruptura da coesão social e, consequentemente, do controle social, estariam, indiretamente, incitando práticas criminais. Tais relações seriam condicionadas por fatores sociais como status econômico, heterogeneidade étnica, mobilidade residencial e, sobretudo, taxas de urbanização e migração".
} 
desorganização social, entre taxas de imigração, urbanização, tamanho populacional e diversas taxas de criminalidade violenta contra pessoas, patrimônios e costumes, nos 853 municípios mineiros, no ano de 2000.

O acima referido pesquisador encontrou padrões espaciais bem definidos, tanto na distribuição das taxas de imigração, quanto de criminalidade violenta, indo mais além ao afirmar a correlação positiva entre os crimes violentos contra o patrimônio e as taxas de imigração, entretanto, adverte que a realidade mineira suporta, na melhor das hipóteses, parcialmente, a tese da vinculação entre imigração e violência urbana, concluindo que "O argumento de que áreas de intensa imigração são favoráveis à incidência criminal, em virtude de serem marcadas por confrontos de valores culturais, desorganização social e fraca coesão social merece investigação mais profunda". (DINIZ, 2005)

Importante ressaltar, também, que tal formato de distribuição dessas populações no espaço urbano acaba por gerar um mecanismo de segregação dos que lá habitam, em razão do mercado de espaços urbanos à disposição destes, ou seja, em razão do poder aquisitivo dessa massa migratória sobram as periferias, as áreas menos valorizadas e urbanizadas das cidades ou, excepcionalmente, quando mais valorizadas, são áreas urbanas imobiliariamente conflituosas, marcadas por disputas judiciais e igualmente carentes de urbanização. ${ }^{45}$

O certo é que o formato de ocupação formal e informal desses lugares são fatores que estão a determinar a configuração das cidades e o desenvolvimento de instrumentos de controle social formal e informal que ali vigoram, refletindo essa sociedade malformada um verdadeiro choque entre realidades culturais e grupos diferentes, o que impulsiona o surgimento de comportamentos delituosos ${ }^{46}$.

Adorno (2002), ao estudar as conexões entre exclusão socioeconômica e violência informa que os registros de mortes violentas revelam maior incidência nos bairros que compõem a periferia urbana, caracterizados pelas precárias condições sociais de existência coletiva e qualidade de vida acentuadamente degradada, concluindo: "Há fortes evidências de que o risco de ser vítima de

\footnotetext{
${ }^{45}$ Na visão de Ferreira e Penna (2005): "Tradicionalmente, a violência costuma ser relacionada à pobreza, à exclusão social, à omissão do Estado, ausência de serviços públicos urbanos e ao próprio processo de urbanização que cria os enclaves de pobreza e as periferias. A complexidade e o crescimento da violência nas cidades têm levado a considerá-la como o resultado da junção de todos esses aspectos, facetas do processo social. É no território que esses diferentes aspectos do processo social se articulam, se interpenetram, se completam e s e contradizem. Admite-se então que a violência também se territorialize".

${ }^{46}$ Shecaira (2012), defende que: "a ausência de mecanismos de controle social e cultural possibilitou o aparecimento de um meio social desorganizado e com potencial criminógeno que se espalha de forma diferenciada pela cidade".
} 
homicídio é significativamente superior entre aqueles que habitam áreas, regiões ou bairros com déficits sociais e de infraestrutura urbana".

Kahn (2005) ao analisar as taxas de homicídio em São Paulo concluiu que é muito nítido que alguns bairros concentram um maior número de mortes enquanto em outros os homicídios foram acontecimentos raros, atribuindo a esse fenômeno espacial de concentração de violência um elevado grau de desigualdade, onde pobres e ricos vivem segregados, sintetizando que "o nível de criminalidade de um determinado local tem muito menos relação com os recursos policiais e judiciais existentes do que com as características sociais e demográficas daquele local". ${ }^{47}$

A partir de tais entendimentos, pressupõe-se que uma das formas de estudar a distribuição de crimes nos espaços urbanos pode ser levada a efeito através da análise da racionalidade da atividade criminosa em contextos ambientais específicos. Assim, através da explicação ecológica do crime, que possui duas vertentes, a teoria da desordem física, que analisa a prática de delitos através de características físicas das localidades e a da desordem social, que analisa a incapacidade da sociedade local integrar valores comuns aos seus moradores e manter assim um efetivo controle social, é possível traçar diagnósticos sobre a criminalidade e a melhor forma de enfrentamento desta. (BEATO E PEIXOTO, 2005)

No mesmo sentido Ferreira e Penna (2005) partem do pressuposto de que a partir de um olhar geográfico sobre a violência é possível detectar a territorialização da mesma, o que levaria a uma maior acuidade na análise de sua dimensão e, consequentemente, ao se admitir o papel do espaço urbano no processo de produção e reprodução da violência pode-se considerar o valor estratégico de tal conhecimento para formulação de estratégias políticas que venham a combater tal mazela social ${ }^{48}$.

Cerqueira e Lobão (2004) reconhecem a complexidade do fenômeno criminal e advertem que é difícil creditar a umas poucas variáveis os determinantes da criminalidade, vez que dependendo da cultura, da região e do momento histórico vivido, determinadas variáveis podem incidir de forma mais decisiva para explicar uma dinâmica criminal específica, assim como, em outros contextos as varáveis podem interagir em vários níveis, conforme apontado no modelo ecológico, fazendo com que as próprias dinâmicas criminais funcionem como motivadoras de outras.

\footnotetext{
${ }^{47}$ Sobre a questão da relação entre violência e desigualdade social, analisando a incidência de homicídios, Cardia e Schiffer (2000) questionam: “Como são essas áreas mais afetadas? O que pode nos ajudar a entender não só a continuidade, mas o crescimento dessa violência? Buscando responder essas perguntas reunimos uma série de dados sobre a cidade relativos àquelas variáveis que são apontadas na literatura como associadas à presença e à ausência de violência: os fatores que representam risco de vitimização e os fatores de proteção contra violência. Entre os fatores de risco, destacam-se a falta de capital social e a superposição de desvantagens; e, entre os fatores de proteção, a presença de capital social, o acesso a direitos - em particular o direito à saúde, à educação, à cultura e ao lazer". Sobre o tema, em profundidade, Ribeiro e Cano (2016).

${ }^{48}$ Maior aprofundamento rm Vesentini (1994).
} 
Caldeira (2000) em aprofundado estudo sobre segregação espacial urbana percebe o fenômeno da violência criminal mais nitidamente a partir da ausência de respostas satisfatórias por parte do controle social formal exercido pelos órgãos do Estado, o que está a estimular a privatização dos processos de vingança, acabando por concluir que "o crescimento da violência não pode ser explicado nem pelas variáveis socioeconômicas e de urbanização nem pelos gastos estatais em segurança pública apenas, mas está relacionado também a uma combinação de fatores socioculturais que culminaram na deslegitimação do sistema judiciário..."

Beato Filho (2012) em estudo específico sobre criminalidade urbana, analisou índices dos 5.505 municípios brasileiros, levando em consideração o que ele denominou como "respeitável tradição sociológica da Escola de Chicago", portanto, a partir da análise espacial aprofundou a constatação da concentração ecológica dos recursos socioeconômicos, mecanismos de segregação espacial e concentração de crimes, concluindo, em apertadíssima síntese, que "os crimes violentos são fenômenos urbanos associados a processos de desorganização nos grandes centros urbanos, nos quais os mecanismos de controle se deterioraram, tal como ocorreu também em outros países." 49

Ribeiro e Cano (2016) ao investigarem a relação entre a dimensão educacional e a violência, chegaram à conclusão que municípios com menores níveis de abandono escolar entre adolescentes apresentam menores taxas de homicídio, devendo, portanto, o indicador educacional ser levado em consideração quando da análise espacial da criminalidade violenta, advertindo que: "como outros estudos revelaram, a educação é uma dimensão central na explicação da distribuição da violência letal".

Em conclusão, para tais autores, os determinantes da criminalidade, são um fenômeno complexo e multifacetado, mas que possui determinadas regularidades estatísticas que variam conforme a região e a dinâmica criminal, em particular ${ }^{50}$.

Em tal contexto e, resgatando as concepções interacionistas, importante frisar que as orientações de conduta do indivíduo no meio em que vive é pautada por orientar os seus atos em função do entorno no qual habita, no ambiente físico e nas relações intersubjetivas que lá desenvolve

\footnotetext{
${ }^{49}$ Especificamente sobre a temática da desorganização nos grandes centros urbanos, cfr. Kleinschmitt et al (2011).

${ }^{50}$ Comparando os índices de desenvolvimento humano entre o Município menos violento do Brasil, Jaraguá do Sul, em Santa Catarina, e o mais violento, Altamira no Pará, o IPEA (2017), elabora um diagnóstico que pode corroborar o que acima exposto, podendo assim ser sintetizado: "junto com o emprego e mercados ilícitos, o desempenho econômico pode levar, indiretamente, a um processo de desorganização social, a partir da migração de trabalhadores e de pessoas em buscas de oportunidades, junto com alterações no espaço urbano e áreas residenciais, que fazem com que haja um esgarçamento do controle social do crime, um aumento de oportunidades para a perpetração de crimes, junto com o aumento da probabilidade de anonimato e de fuga do criminoso. A situação acima ocorre quando as transformações urbanas e sociais acontecem rapidamente e sem as devidas políticas públicas preventivas e de controle, não apenas no campo da segurança pública, mas também do ordenamento urbano e prevenção social, que envolve educação, assistência social, cultura e saúde...".
} 
a partir do que estes significam para ela, ou seja, tal significado surge como consequência da interação social que este indivíduo mantem com seu próximo, com as pessoas e seu ambiente de convivência, sendo tais significados manipulados e modificados mediante um processo interpretativo desenvolvido por este ao defrontar-se com as situações que vai encontrando em sua rotina diária ${ }^{51}$.

Assim, em maior ou menor medida, os estudos acima apresentados parecem aproximarem-se dos fundamentos centrais desenvolvidos pelos sociólogos da Escola de Chicago, que apontam a disputa pelos espaços urbanos, a segregação da população mais pobre em áreas de precária situação urbanística, a intensa desorganização social fruto do processo de enfraquecimento dos laços comunitários e familiares ${ }^{52}$, agregados a baixíssimos níveis educacionais e culturais e intenso desemprego, como fatores que podem influenciar na prática criminosa.

\section{O MUNICíPIO E AS POLÍTICAS PÚBLICAS DE REORGANIZAÇÃO SOCIAL E URBANA COMO INSTRUMENTOS DE SOCIALIZAÇÃO E COMBATE À CRIMINALIDADE}

\section{1 - Políticas Públicas e a Constituição brasileira de 1988}

Pelo que até agora exposto no presente texto, podemos inferir que o desenvolvimento de políticas públicas com investimentos nas áreas de organização pela via da inclusão social e urbanização nas comunidades, além de serem direitos constitucionalmente previstos, apresentam impacto positivo em todos os setores da sociedade, vez que direcionados ao combate da violência estrutural e, por essa via, acabam por privilegiar o reconhecimento da cidadania.

Em razão de tal posicionamento, entende-se desnecessário vincular o resultado de tais políticas ao imediatismo de números que possam demonstrar queda nos índices de criminalidade, ou seja, independentemente do alcance estatístico - que pode ser relativizado ante o tempo necessário para obtenção de resultados - de tais políticas na esfera da violência criminal| ${ }^{53}$, deve-se investir, ainda

\footnotetext{
${ }^{51}$ Sobre o assunto, sob o prisma da psicologia social, cfr. Carvalho et al (2010).

52 Sobre o assunto, especificamente, Delgado (2014):.

${ }^{53}$ Skogan (2012, p. 175, tradução livre) chama a atenção para o fato de que: "Pesquisadores usam amostras de pesquisas, dados administrativos e observação de campo para demonstrar a magnitude e a distribuição diferenciada da desordem nas vizinhanças, em razão de suas particularidades. Entretanto, os resultados de tais pesquisas são, em geral, os mesmos, independentemente do método adotado. Desordem, independentemente, mas sempre em conjunto com a prática de crimes exerce um papel de desestabilização nos bairros urbanos, diminuindo as possibilidades do controle social informal, desencorajando investimentos e estimulando o medo do crime. Deste modo, independentemente das interrelações entre desordem e criminalidade tais justificativas já são suficientes para que os gestores atentem para a necessidade de políticas que reduzam a desordem física e social".
} 
que a longo prazo, na via alternativa de combate à criminalidade representada pelas políticas públicas não reativas/repressivas ${ }^{54}$.

Essa fórmula carrega consigo o benefício de estar envolta na categorização de política pública social, pensada na linguagem dos direitos, se distanciando, portanto, da ocupação territorial por parte do Estado como apenas um recurso de controle do crime subsidiário à repressão policial e, por outro lado, se aproximando de uma perspectiva claramente constitucionalizada de atuação política.

Consequentemente, a compreensão do significado de ordem pública acaba por ultrapassar as fronteiras das medidas de controle exclusivamente repressivas, evoluindo, isto sim, para uma ambiência na qual as medidas de cunho coercitivo passam paulatinamente a ser substituídas por medidas de cunho integrador, socializador e apaziguador, retrocedendo-se a um tempo no qual a ordem social era pautada nos processos de negociação, convencimento e aceitação voluntária dos valores e normas que regulam as condutas ${ }^{55}$.

Para que não haja mal entendidos, importante que se frise que ao adotarmos o entendimento segundo o qual as Políticas Públicas não repressivas nos parecem estar mais próximas aos anseios de uma Constituição programática, mormente na esfera dos direitos sociais, tal posicionamento não invalida e nem descarta o importante papel concomitante que as ações de cunho repressivo possam representar no atual momento da história brasileira em sede de políticas de Segurança Pública.

O certo é que ao nos filiarmos à adoção de Políticas Criminais alternativas o fizemos com base nos fundamentos até aqui apresentados e adotados, levando, prioritariamente, em consideração as explicações pertinentes ao cometimento de ações delituosas nos estudos proporcionados pela Escola Sociológica de Chicago, reforçados através de uma ampla revisão bibliográfica que retratou o estado das pesquisas realizadas no Brasil sobre tal temática, inferindo-se, finalmente, pela procedência das teses que inter-relacionam desorganização social com desorganização urbana e ambas com determinado tipo de criminalidade.

Isto posto, agora se faz necessário detalhar e aprofundar mais o estudo sobre os mecanismos, meios e Instituições através dos quais se possa desenvolver as Políticas Públicas almejadas e, de modo concreto, que se proponham caminhos para o enfrentamento do problema ${ }^{56}$.

\footnotetext{
54 Na visão de Soares (2003): “No plano municipal há muito a fazer, mesmo sem as polícias. Nesse nível, a intervenção efetivamente capaz de prevenir a violência e a criminalidade é aquela que visa a alteração das condições propiciatórias imediatas, isto é, das condições diretamente ligadas às práticas que se deseja eliminar". 55 Para maior aprofundamento no tema, cfr. Silva (2014).

${ }^{56}$ Após extensa pesquisa sobre os determinantes da criminalidade violenta, onde investigaram as ligações entre características demográficas: estrutura, dinâmica e composição; Estrutura socioeconômica: renda, pobreza, desigualdade de renda; Mercado de trabalho: atividade, desocupação, informalidade; Educação: nível educacional, atendimento à escola, fluxos discentes; Serviços urbanos, condições de vida e de moradia; Vulnerabilidade familiar e estilos de vida; Políticas públicas e despesas orçamentárias municipais e violência letal, Ribeiro e Cano (2016) chegaram à seguinte conclusão: “Do ponto de vista das políticas públicas, os resultados
} 
Nessa trilha, a Constituição Federal brasileira de 1988 trouxe fundamentos e orientações - vez que, como já dito, é tida como uma Constituição programática - para uma maior intervenção social por parte do poder público, pois ampliou o leque de direitos sociais e o campo da proteção social sob a responsabilidade do Estado, com destaque para as políticas, beneficiários e benefícios. (JACCOUD, 2005)

Para efeitos deste trabalho adotaremos, então, enquanto terminologia, a acepção políticas públicas sob dois enfoques: no primeiro momento, como significado da ação estatal com vistas à obtenção de um fim, mais especificamente pela efetivação dos direitos fundamentais, em um plano mais abstrato; no segundo enfoque, compreendemos políticas públicas como o conjunto de ações, desde o planejamento até as ações executivas, que refletem a atuação concreta por parte do Estado para alcance do fim acima delineado ${ }^{57}$.

Assim entendendo, fácil concluir que as políticas públicas servem para dar concretude aos direitos fundamentais previstos na Constituição Federal, entretanto, para que sejam implementados necessitam do interesse dos políticos democraticamente eleitos, haja vista ser de suas competências o planejamento e execução destas, ou seja, é pela via da discricionariedade que os programas de governo são pensados e executados, pois os governantes gozam da liberdade para definição do campo, escolha do conteúdo e momento para execução das políticas públicas.

Adotando tal linha de entendimento, fica bastante claro, no planejamento levado a efeito pelas autoridades competentes no Brasil, pelo menos desde o ano 2000 - quando do lançamento do Plano Nacional de Segurança Pública -, portanto, dois anos após e entrada em vigor da Constituição Federal de 1988, que as ações não repressivas e um maior destaque aos Munícipios tem prevalecido nas políticas afetas à Segurança Pública ${ }^{58}$.

Tal direcionamento deve-se ao reconhecimento de que, paulatinamente, os entes municipais têm dispensado maior atenção no trato da Segurança Pública. Inegável, destarte, de que há o nítido desenvolvimento da ideia segundo a qual muitas soluções de políticas públicas implicam ações locais, com foco no território, assim como diversos Municípios passaram a priorizar a Segurança Pública no planejamento político nas últimas legislaturas, alocando mais verbas e envidando esforços para a

desse estudo parecem favorecer o investimento em programas de transferência de renda e de programas educacionais como os mais adequados para a prevenção da violência letal".

${ }^{57}$ Tal conceito foi concebido a partir da leitura do texto de Goodin et al. (2008). Um aprofundado estudo sobre Políticas Públicas realizado na Universidade de Oxford, com riqueza de detalhes, pode ser encontrado em Moran et al (2008).

58 Cfr. os Planos Nacionais de Segurança Pública dos anos 2000 e 2017, assim como a Política Nacional de Segurança Pública de 2018. Sobre as relações entre Urbanismo, Segurança e Lei, cfr. Fernandes (2009).. 
criação de Secretarias de Segurança Urbana, criação e aparelhamento das Guardas Municipais, além da implantação dos Conselhos Comunitários de Segurança ${ }^{59}$.

Um exemplo paradigmático deste direcionamento foi, no ano de 2007, o lançamento do Programa Nacional de Segurança Pública com Cidadania - $\mathrm{PRONASCI}{ }^{60}$, que respeitando a linha de continuidade que atravessou os sucessivos planos e programas afetos à Segurança Pública, fortaleceu e consolidou a perspectiva de constitucionalização desta matéria, reconhecendo que a integração intergovernamental entre a União, Estados e Municípios, assim como entre os poderes Legislativo, Executivo e Judiciário, aliados à gestão intersetorial de projetos, com a participação de todos os entes federados através de seus ministérios ou secretarias, possibilitaria um melhor atendimento às demandas sociais garantidas pela Carta Magna.

Em síntese, com a adoção de uma linha de desenvolvimento de Políticas Públicas de Segurança não repressivas, o Poder Político acaba por se aproximar de maneira bastante incisiva dos ditames previstos constitucionalmente, nos quais há claramente um direcionamento pela busca de efetivação de ações inclusivas que venham a concretizar os direitos e garantias, mormente os de cunho social, assegurados abstratamente pela Carta Magna.

Por fim, entendemos ser os Municípios ${ }^{61}$ os entes federados mais indicados para elaborar o planejamento e concretizar ações que venham a atender tais reclames constitucionais em sede de políticas de segurança a cargo dos poderes públicos.

\footnotetext{
${ }^{59}$ Um estudo aprofundado sobre a paulatina inserção dos Municípios brasileiros na área da Segurança Pública pode ser encontrado em Peres et al (2016, p. 52), para quem: "Este texto buscou reconhecer o papel dos municípios no campo da segurança pública, apontando para a necessidade de melhor compreendê-los e avaliálos em sua atuação. Se do ponto de vista da execução orçamentária é preciso reconhecer o protagonismo que esses atores locais assumiram no financiamento da segurança pública, é forçoso admitir, a partir do cenário descrito, que não tem havido uma atuação sistêmica com coordenação do governo federal que consiga dar clareza, coesão e efetividade a esses gastos dos entes locais. Desse modo, faz-se necessário repensar a atuação da União e sua capacidade de organizar e coordenar ações em uma política nacional de segurança pública para que se consiga estabelecer critérios e padrões de atuação, sem desconsiderar as especificidades locais, limitações e necessidades das cidades brasileiras".

${ }^{60}$ Cfr. Lei 11.530 de 2007 que instituiu o PRONASCI.

${ }^{61} \mathrm{Em}$ esclarecedora síntese Ortuño Rodrigues (2010, p. 17, tradução livre) pontua: "O Município, marco por excelência da convivência civil, devido aos interesses que lhe são próprios e pelo próprio devir espontâneo dos assentamentos humanos, se erige como principal e primária entidade territorial onde se produz esta interrelação de direitos e liberdades dos indivíduos, devendo ser destacado que - do mesmo modo que se sucede nas restantes administrações locais - é uma corporação pública (territorial), em cujo governo e administração se prioriza o componente pessoal, ao integrar-se de forma direta os órgãos reitores e gestores pelos representantes livremente por seus cidadãos".
} 


\subsection{Do incremento nas políticas públicas de municipalização da Segurança Cidadã}

Ante as exigências acima apontadas e pela linearidade do que neste trabalho temos articulado, ou seja, intervenções ambientais de cunho social e urbanístico como políticas públicas para enfrentamento da violência - estrutural e criminal - e criminalidade ${ }^{62}$, entendemos que o caminho a ser seguido passa, sem a menor sombra de dúvidas, pelo aumento da participação municipal $\left.\right|^{63}$ na implementação e execução de políticas públicas que tenham a capacidade de diminuir a violência e a criminalidade e, portanto, incrementar resultados positivos em nível global de segurança pública ${ }^{64}$.

Importante frisar, desde já, que as políticas públicas em âmbito municipal aqui propostas, em nenhuma hipótese objetivam oposição ou substituição às necessárias medidas de cunho repressivo policial, de melhoria do sistema formal de controle social, de investimentos massivos em educação, dentre outras políticas afetas ao disciplinamento da sociedade, vez que temos plena consciência de que as medidas interventivas de cunho social e urbanístico demandam tempo para apresentarem resultados e devem ser implementadas em concomitância com outras medidas de ordem e disciplina ${ }^{65}$.

Entretanto, em razão das enormes discrepâncias orçamentárias entre os Municípios brasileiros, cujos reflexos para as menores cidades incidirão diretamente na possibilidade de criação e manutenção das Guardas Municipais e, portanto, nas possibilidades de combate à violência pela via institucionalizada do policiamento, parece-nos mais pertinente que os Municípios invistam mais na criação de condições positivas de convivência, buscando a redução das tensões sociais, deixando o combate direto à delinquência pela via repressiva a cargo dos Governos Federal e Estaduais ${ }^{66}$.

Nesse sentido, várias medidas de caráter não repressivo poderiam ser levadas a efeito para efetivar os direitos fundamentais sociais, econômicos e urbanísticos de seus habitantes, previstos constitucionalmente, como já dito, e que teriam por consequência concomitante a diminuição da violência estrutural e, certamente, o paulatino decréscimo dos índices de violência criminal ${ }^{67}$.

\footnotetext{
${ }^{62}$ Sobre a importância do exercício da cidadania em tal processo de intervenções de cunho social e urbanístico, como forma de consolidação dos direitos assegurados constitucionalmente, em profundidade, Andrade (2003b). ${ }^{63}$ Sobre o tema, cfr. Guimarães e Pereira (2014, p. 825-826), para quem: "Nesse sentido, a municipalidade poderia agir com a implementação de políticas públicas preventivas, através do controle social informal, no lugar de políticas repressivas, recuperando-se espaços e serviços públicos degradados, conjuntamente com o fortalecimento dos laços sociais comunitários, integrando-se e recuperando-se as áreas degradadas, para se oferecer espaços públicos capazes de agregar o sentimento de comunidade e de civilidade".

${ }^{64}$ Cfr. Ruiz Rodrígues (2010).

${ }^{65}$ Sobre a complexidade no processo de escolha de políticas públicas adequadas ao enfrentamento do crime, cfr. Oliveira (1987). Sobre a Segurança Pública nas grandes cidades brasileiras, cfr. Vendramini (2010, p. 49), para quem: "As cidades estão cada vez mais procurando descentralizar os seus serviços de forma a atingir a população como um todo. As grandes cidades já possuem uma atividade de gestão descentralizada de forma a proporcionar a oferta de serviços públicos mais próximos da população".

${ }^{66}$ Assim, Barbosa et al (2008). Sobre o tema, cfr., também, Felgueiras (2009).

${ }^{67}$ Sobre estratégias de prevenção criminal, por todos, Welsh e Farrington (2016).
} 
Concretamente, estamos a falar de Intervenções urbanísticas, conforme previsto no Estatuto das Cidades ${ }^{68}$, como a estruturação da rede de transporte público de massas eficiente e integrado entre todas as regiões da cidade, a recuperação das áreas fisicamente degradadas, a criação de espaços públicos de lazer com vistas à integração social local, como parques, clubes, espaços culturais, quadras esportivas, dentre outros ${ }^{69}$.

Ademais, devem ser implementadas intervenções no âmbito do controle social informal, como o desenvolvimento de projetos executados pela própria comunidade ou através de organizações não governamentais, com enfoque especial na juventude que está a ser cooptada pelo crime, no sentido de compreender criticamente a dinâmica criminal na e da comunidade, explorando meios de intervenção próprios, de acordo com aquela realidade específica e direcionando as demandas ao poder público atinentes ao diagnóstico traçado ${ }^{70}$.

$\mathrm{Na}$ busca do alcance deste amplo objetivo de organização social e urbana de espaços específicos, devem ser priorizadas, também, ações que se encontrem na esfera da prevenção primária, cujo foco esteja centrado na redução da desigualdade econômica, de promoção da educação e saúde, do esporte, lazer e cultura, de prevenção e tratamento do abuso de álcool e drogas, de assistência às famílias, de assistência religiosa, enfim, ações que fortaleçam os laços comunitários e, consequentemente, auxiliem no desenvolvimento do controle social informal no seio da comunidade.

Portanto, reafirmamos, inobstante a possibilidade de qualquer ente federativo atuar especificamente em determinada área, através de projetos elaborados com as finalidades acima expostas, é fácil reconhecer que o Município - no qual a área objeto de maior atenção em razão dos níveis de violência apresentados está incorporada - é o ente federativo mais apropriado para levar a efeito o tipo de intervenção aqui proposta ${ }^{71}$.

\footnotetext{
${ }^{68}$ Cfr. Lei $10.257 / 2001$.

${ }^{69}$ Sobre o assunto, cfr. Kahn (2005) e Carmona (2014, p. 38), para quem: “...o lazer é poderoso aliado na diminuição das tensões sociais, dificultando o surgimento da criminalidade, principalmente em relação ao segmento infanto-juvenil, maiores vítimas e autores da violência urbana. [...] vários estudos comprovaram que a efetivação do direito ao lazer ao jovem constitui forte instrumento no combate à violência urbana".

${ }^{70} \mathrm{Em}$ tal seara, muito pertinente o pensamento de Soares (2003), para quem: "Seria necessário instituir fontes alternativas de atração ou recrutamento dos jovens, capazes de competir com o tráfico, oferecendo pelo menos as mesmas vantagens proporcionadas por ele. Em outras palavras, para competir com a fonte de sedução criminosa, o poder público municipal teria de proporcionar benefícios materiais, como emprego e renda, e simbólico-afetivos, como valorização, acolhimento e pertencimento, restituindo visibilidade e autoestima, o que, por sua vez, exigiria uma espécie de "customização" das políticas públicas".

${ }^{71} \mathrm{Em}$ pesquisa realizada para mensurar o nível de adoção de mecanismos de gestão em Segurança Pública pelos Municípios brasileiros, Lima et al (2014, p. 406) concluíram que: "O estudo mostrou o baixo grau de implementação de mecanismos de gestão da segurança pública nos municípios brasileiros. Os municípios são omissos no tratamento preventivo da segurança pública e seguem a mesma trajetória dos poderes estaduais e federais, ou seja, a adoção de uma postura reativa, cujo resultado é conhecido por toda a sociedade: a ineficiência na redução das taxas de criminalidade"
} 
É preciso sempre lembrar que as demandas apresentadas prioritariamente às cidades estão sempre relacionadas ao desenvolvimento de políticas públicas que objetivem a melhoria das condições de vida e habitabilidade de seus moradores, o que pressupõe a melhoria das condições socioeconômicas destes e, por isso mesmo, as políticas públicas voltadas para a melhoria das condições de segurança pública, ao serem implementadas, devem levar em consideração tais demandas sociais.

Neste ponto, exsurge a importância da análise da estrutura federativa do Brasil, que conta com a União, 26 Estados, o Distrito Federal e 5.070 Municípios, o que denota, claramente, a diferenciação na possibilidade de interferência da sociedade civil, de maneira mais ampla e da interferência comunitária, em uma perspectiva mais específica, nas políticas públicas de segurança a serem desenvolvidas, assim como, que menores áreas permitem a elaboração de um diagnóstico mais preciso sobre os problemas a serem enfrentados, até mesmo pela profunda diversificação territorial, social e cultural brasileira.

Assim sendo, é fato incontestável que o Município é, dentre todos os organismos de gestão política, aquele que está mais próximo do cidadão, sendo a área geográfica que sofre os efeitos diretos da violência, oriundos dos bairros que the integram por serem social e urbanisticamente desorganizados, se constituindo, assim, como o espaço específico no qual devem ser diagnosticados os problemas e implementadas as possíveis soluções aos mesmos.

Ademais, como ponto crucial da discussão, deve ser levada em conta a questão da legalidade, ou seja, dos limites impostos constitucionalmente aos Municípios para atuar em sede de Segurança Pública.

Desse modo e, para evitar controvérsias e obstáculos ao desenvolvimento de Políticas Criminais no âmbito não repressivo/reativo, acabamos por concordar com o entendimento segundo o qual os Municípios somente estão aptos a operar, em questões de segurança pública, nesse tipo de intervenção aqui proposta - inclusivas e preventivas -, haja vista que as Guardas Municipais, de acordo com o artigo 144, § 8ㅇ, da Constituição Federal, ainda não tem respaldo jurídico para fazerem intervenções repressivas ${ }^{72}$.

Às Guardas Municipais, portanto, parece-nos ser mais apropriado desempenhar um papel integrador entre o poder público e as comunidades ${ }^{73}$, quando no exercício de sua função de polícia pautar sua atuação no respeito aos direitos humanos, à diversidade e à divergência, promovendo e

\footnotetext{
${ }^{72}$ Entendimento esposado no Mandado de Injunção N. 6793 - STF de 05/02/2018. Sob uma perspectiva formal, com análise da municipalização da Segurança Pública a partir do Plano Nacional de Segurança Pública, que prevê a criação do Plano Municipal de Segurança, do Conselho Municipal de Segurança, do Fundo Municipal de Segurança, da Secretaria Municipal de Segurança Pública e da Guarda Municipal, cfr. Lima et al (2014).

${ }^{73}$ Sobre o papel da Polícia na segurança urbana, cfr. Clemente (2009).
} 
estimulando a cidadania participativa pela via da efetivação dos programas de reorganização social e urbanística implantados nas comunidades como meio de combate às violências estrutural e criminal ${ }^{74}$.

A diminuição do aspecto repressivo aliado ao alargamento do aspecto integrador produzirá por parte das Polícias Municipais, destarte, um necessário fortalecimento das relações entre os moradores e as autoridades públicas, sedimentando o compromisso em prol das melhorias almejadas pela comunidade e concretizadas pelo poder político municipal.

Assim sendo, como visto acima, às Polícias Municipais se abre o fértil campo das políticas de segurança pautadas na prevenção situacional, políticas estas que se assentam no objetivo prioritário de redução das oportunidades para o cometimento de atos criminosos e que podem ser expandidas no sentido da vídeo vigilância ${ }^{75}$, da arquitetura contra o crime, da neighbourhood watch, entre outras tantas técnicas de prevenção utilizadas hodiernamente e que necessitam do gerenciamento do Poder Público Municipal. ${ }^{76}$

Nesse caminhar, um dos grandes avanços em matéria de Segurança Pública de viés preventivo e municipal no Brasil foi a previsão constante no Fundo Nacional de Segurança Pública - FNSP, criado pela Lei 10.201/2001, da criação de Conselhos Municipais de Segurança, que permitem à comunidade ter acesso e participação ao processo decisório sobre as prioridades e a forma como os recursos públicos devem ser alocados, no que pertine às necessidades locais de Segurança Pública ${ }^{77}$.

Tais Conselhos representam um imprescindível elo de ligação entre as necessidades específicas da comunidade e os órgãos de planejamento, gestão e execução de políticas setorizadas de Segurança Pública.

Já no ano de 2000, quando do lançamento do Plano Nacional de Segurança Pública - PNSP, diversos pontos de atuação do mesmo previam a adoção das medidas aqui defendidas, assim como, a imprescindível atuação dos Municípios no âmbito da Segurança Pública ${ }^{78}$.

\footnotetext{
${ }^{74}$ Sobre o tema, cfr. Barbosa et al (2008), Sobre o assunto, cfr., também, Ricardo e Caruso (2007).

${ }^{75}$ Sobre o tema, especificamente, cfr. Valente (2009).

${ }^{76}$ Especificamente sobre esta temática, em detalhes, cfr. Wilson e Kelling (2008) para quem deve ser evitada uma grande concentração das atividades policiais na criminalidade mais grave, devendo, isto sim, o poder público voltar sua atenção para a proteção comunitária pela via do combate às incivilidades, vez que estas podem destruir uma comunidade muito mais rápido que qualquer equipe de ladrões profissionais.

$77 \mathrm{Em}$ 06/01/17, um novo Plano Nacional de Segurança Pública foi lançado pelo Governo do Presidente Michel Temer, reconhecendo o importante papel que os municípios podem desempenhar no âmbito do combate à criminalidade.

${ }^{78}$ Apoiar e incentivar a criação de guardas municipais desmilitarizadas e desvinculadas da força policial, estabelecendo atribuições nas atividades de segurança pública e adequada capacitação, inclusive para a área de trânsito. Sensibilizar e apoiar financeiramente projetos municipais que invistam na qualidade de vida de populações que vivem em periferias, favelas e zonas de carência, na instalação de equipamentos sociais que reduzam circunstâncias ou situações que facilitam a ação criminosa. Mapear os espaços públicos que estejam deteriorados, importantes para a comunidade, com ênfase em zonas de maior carência social e urbana, visando sua recuperação estética e moral. A partir da restauração de sua representação comunitária, evitar que sejam
} 
Mais recentemente, a minuta do documento denominado Política Nacional de Segurança Pública - PNASP ${ }^{79}$ com previsão para ser iniciado em fevereiro de 2018 , esteve disponível no site do Ministério da Justiça e Segurança Pública do Governo Federal para consulta pública e, consequentes, sugestões e também privilegia o papel dos Municípios nas políticas de prevenção e combate ao crime.

A partir do entendimento acima exposto, segundo o qual o Município é o ente federado mais apto para a gestão de políticas de segurança não repressivas, assim como aquele que está mais próximo do cidadão, necessário aprofundar qual o papel a ser desempenhado por estes a partir das perspectivas das Políticas Públicas de Segurança aqui defendidas, ou seja, a partir de um modelo preventivo e inclusivo de Segurança Pública que privilegia a participação das comunidades na busca de soluções para o enfrentamento da violência estrutural e da violência criminal.

Garland (2007) foi um dos primeiros pesquisadores a detectar que, em razão da ausência satisfatória de respostas à crescente violência, ainda na vigência do Estado de bem estar social, houve uma mudança cultural na qual, paulatinamente, os cidadãos passaram a se preocupar mais com segurança e, assim, passarem a exercer um certo protagonismo nesta área, caracterizando uma profunda mudança nas práticas sociais até então em voga.

Assim, atitudes preventivas levadas a efeito pelos cidadãos passaram a ser vistas como uma opção concomitante às medidas convencionais de controle social formal sob responsabilidade do Estado.

A partir de então, com maior intensidade entre Municípios e comunidades, foram se desenvolvendo as Políticas Públicas de Segurança hoje conhecidas como prevenção situacional, prevenção comunitária, segurança cidadã, aliança preventiva, dentre outros termos e com objetivos variados, mas que em comum, como já dito, apresentam uma prioritária participação das comunidades, através de seus cidadãos, no trato das questões afetas ao controle social ${ }^{80}$.

tolerados, por toda a comunidade, agressões como: grafitismos, depredações, uso inadequados de praças, brinquedos, telefones públicos, lixeiras, etc. Estimular atitudes positivas de preservação e que materializem a ideia de que o espaço público é a representação da própria comunidade e que esta se assenta no respeito e no cumprimento da lei que, nesse caso, é, principalmente, o dever de cada um com os demais. (PNSP, 2010)

${ }^{79}$ A Política Nacional de Segurança Pública (PNASP, 2018) é o conjunto de princípios, diretrizes, objetivos que condicionará a estratégia de segurança pública a ser implementada pelos três níveis de governo de forma integrada e coordenada, visando à preservação da vida, à manutenção da ordem pública, ao meio ambiente conservado a garantia da incolumidade das pessoas e do patrimônio, o enfrentamento e prevenção à criminalidade e à violência em todas as suas formas, assim como o engajamento da sociedade, a transparência e publicidade das boas práticas.

${ }^{80}$ Na visão de Garland (2007, p. 254-255, tradução livre), "As reações adaptativas à nova experiencia do crime por parte dos cidadãos particulares, dos locais e das comunidades têm apresentado uma trajetória parecida e tem produzido similares efeitos institucionalizadores. Ao largo do tempo começou a surgir um padrão de resposta e adaptação a partir da forma de como as pessoas tomavam mais precauções rotineiras contra a criminalidade. Como a maioria das mudanças sociais, esta transformação foi lenta e inconsciente a princípio, e foi liderada por pequenos setores da população, particularmente os proprietários de imóveis da classe média e 
É por esta via, portanto, que entendemos devam ser expendidos esforços políticos e comunitários, assim como, destinados massivos recursos financeiros que tenham a capacidade de enfrentar a crescente violência estrutural, que traz a reboque a violência criminal, cuja intensidade é mais acentuada em determinados espaços físicos e, por via de consequência, atingem de maneira mais intensa determinada parcela da população.

O perfil de Política Criminal aqui adotado, como alhures insistentemente repetido, tem como pressuposto, assim como consequência, uma imprescindível participação dos cidadãos, o que configura a cidadania ativa e, por esta via, paulatinamente, vai se construindo uma composição demográfica racional, na qual as capacidades de escolha política e gerenciamento daquilo que programado e que deram origem a tais escolhas para representação política da comunidade, vão se intensificando, acarretando, como profícua conclusão deste processo democrático, o monitoramento e a cobrança pela efetivação de todas as políticas propostas.

A conjugação de todos estes fatores acaba por configurar um panorama de fortalecimento dos laços comunitários e do relacionamento entre comunidade e Municípios através da necessária integração para desenvolvimento das Políticas Públicas de Segurança e, ineludivelmente, no transcorrer deste processo está a se fortalecer a democracia e o Estado de Direito.

A partir de tal posicionamento, portanto, podemos adotar o entendimento de que estamos a transitar no campo de uma Segurança Pública Cidadã ${ }^{81}$.

Assim sendo, na perspectiva de Políticas Públicas de Segurança Cidadã aqui adotada, comunidade, especialistas e gestores, de maneira amplamente compartilhada, elaboram as diretrizes para implantação de ações que tenham como foco a prevenção da violência e a promoção de convivência social segura e pacífica, com respeito aos direitos humanos, desenvolvendo os projetos a partir do diagnóstico dos problemas, formulação do planejamento, implementação, monitoramento e avaliação das ações em curso.

Deste modo, para que seja possível a concretização de Políticas Públicas de Segurança Cidadã, devem os Municípios atuar através de estratégias estatais e sociais de natureza preventiva como forma de redução do crime e da violência, dos danos oriundos das condutas delitivas, da reincidência e da vitimização, quer seja através de políticas universais, quer seja através de políticas focalizadas ${ }^{82}$.

profissionais jovens e estabilizados que começaram a residir em áreas que haviam sofrido um processo de deterioração mas que se encontravam sendo recuperadas por meio de processos de recuperação urbanística". ${ }^{81} \mathrm{Um}$ estudo especifico e muito detalhado sobre segurança cidadã no Brasil, pode ser encontrado em Mesquita Neto (2006).

${ }^{82}$ Sobre as vantagens e desvantagens das políticas universais e focalizadas, cfr. Mesquita Neto (2006). 
Para tanto, entendemos que se afigura como pressuposto inafastável, em razão da própria estrutura federativa do Estado brasileiro acima exposta, que o estabelecimento de convênios com os Estados e Governo Federal seja o primeiro passo a ser dado para que se torne possível o desenvolvimento das políticas públicas aqui propostas, vez que a maioria das cidades brasileiras não têm orçamento próprio suficiente para a concretização de tais medidas.

Quando da executividade, além de todas as medidas de caráter mais geral, já apontadas ao longo do trabalho e especialmente no presente capítulo - a partir dos postulados da Escola de Chicago -, priorizando-se o empoderamento dos Municípios e a democratização no âmbito do diagnóstico dos problemas, formulação do planejamento, implementação, monitoramento e avaliação das ações em curso, com vistas a promoção da segurança das comunidades pautada no respeito aos direitos humanos, entendemos devam ser implementadas, de modo bem específico, as seguintes medidas:

Implantar serviços de georreferenciamento contínuo, o qual deverá disponibilizar dados qualitativos e quantitativos sobre a violência e criminalidade na comunidade e, por essa via, facilitar o diagnóstico e o planejamento das ações para enfrentamento do problema;

Desenvolver programas de patrulhamento, ronda e vigilância intensiva da Guarda Municipal, com a necessária aproximação da comunidade, visando concretizar os fundamentos de um policiamento comunitário de proximidade e utilizando-se toda a tecnologia possível e disponível;

Implantar, desenvolver e, amplamente, disponibilizar nas comunidades programas de educação e profissionalização de crianças, adolescentes e jovens, priorizando a inclusão digital e o ensino nas áreas que possibilitem a inclusão no mercado de trabalho;

Programas que objetivem enfrentar o grave problema das famílias desestruturadas, do analfabetismo, da dependência química, do ociosidade que leva à fácil cooptação pelas organizações criminosas, devem ter prioridade caso se queira efetivamente avançar na estruturação das comunidades assoladas pela desorganização social;

Desenvolver, de forma bem específica, programas de enfrentamento à violência doméstica;

Programas do esporte, artes e cultura contra o crime devem ser imediatamente implantados e massivamente estimulados, até porque se apresentam como uma alternativa para a juventude de determinadas localidades que hodiernamente somente encontra disponibilidade de escolha entre as diversas organizações criminosas na qual deseje se filiar, ou seja, dependendo do local onde se encontra a comunidade, ao jovem resta escolher entre o PCC ou o Comando Vermelho;

Ocupar os espaços públicos de forma democrática, ou seja, as ruas, os parques, as praças, os complexos culturais e esportivos devem ser ocupados pela população, para que os mesmos não se deteriorem e se transformem em espaços propícios para o cometimento de delitos; 
Regulamentar e fiscalizar a realização de festas em locais públicos, combatendo de forma veemente a utilização de aparelhos sonoros (paredões ou pancadões de som) que causem poluição sonora e, desta forma, perturbação do sossego público, assim como fiscalizar a venda e consumo de drogas lícitas e ilícitas em tais eventos;

Devem ser implantados programas contínuos de treinamento e atualização dos funcionários públicos que irão desenvolver as atividades junto às comunidades, assim como, estimulados tais programas em sede das organizações não governamentais;

A necessária aproximação entre as Policias Estaduais e as Guardas Municipais é uma etapa imprescindível para que todas as ações propostas sejam fortalecidas, haja vista que a presença da Polícia Militar, principalmente, é uma constante no meio das comunidades e tal aproximação deve ser feita pela via do policiamento comunitário de proximidade, que se constitui como o alicerce no relacionamento pautado na confiança entre os moradores e o Poder Público;

As Polícias, portanto, precisam trabalhar no âmbito das Políticas Públicas de Segurança preventivas em uníssono, sempre priorizando o diálogo e o entendimento com as comunidades, o que é imanente a tal tipo de ação, podendo ficar a cargo das mesmas a gestão de um Centro de Mediação de Conflitos;

Integrar, entre si e com a comunidade, todos os atores que fazem parte do Sistema de Controle Social Formal, como Policiais, Promotores de Justiça, Juízes de Direito, Defensores Públicos, Assistentes Sociais, Profissionais da área de Comunicação, dentre outros profissionais que necessariamente atuarão em uma ou mais fases do desenvolvimento das políticas a serem implementadas, nos parece ser, também, uma imprescindível providência diretamente relacionada ao sucesso de tais políticas;

Implantar e manter grupos de trabalho intersetorizados, interdisciplinares e multidisciplinares para dar suporte a importante missão de diagnóstico dos problemas, formulação do planejamento, implementação, monitoramento e avaliação das políticas públicas em fase de concretização;

Por fim, imprescindível que as ações implementadas tenham continuidade, independentemente do grupo político que se encontre na posição de gestor, o que não significa não poderem os programas serem avaliados e alterados, preservando-se, entretanto, a ideia matriz de desenvolvimento de Políticas Públicas de Segurança no âmbito municipal pautadas em uma perspectiva inclusiva e preventiva - portanto, cidadã -, focadas no combate à violência estrutural, representada pela desorganização social e urbana, como forma de enfrentamento da violência criminal. 


\section{CONCLUSÃO}

Neste trabalho, procurou-se investigar, com base na literatura, uma das várias teorias que explicariam o comportamento desviante e criminoso. Fez-se um apanhado de algumas das mais substantivas contribuições, cujas orientações metodológicas englobaram aquelas utilizadas pelos autores que acabaram por conformar o que, nos dias atuais, se denomina de Escola Sociológica de Chicago.

Assim, para estruturar um posicionamento defensável em sede de Políticas Públicas de Segurança, várias foram as temáticas enfrentadas, caracterizadas todas elas pelo dissenso, haja vista que nenhum dos tópicos abordados apresenta qualquer pacificação doutrinária ou, pelo menos, uma tendência claramente majoritária.

Por este caminho, descreveu-se o núcleo e a lógica por trás dos estudos desenvolvidos por aquela sociologia, tendo consciência plena de que o conjunto de teorias aqui apresentado, por certo, não esgota o universo das teorias de causação do crime, ainda que possibilitem uma compreensão bastante acurada do pensamento de estudiosos sobre essa temática, desde o século passado.

Assim, o presente estudo contribui para o debate sobre a relação entre formas de inclusão social e espacial das camadas sociais menos favorecidas da população brasileira - via de regra segregadas nas periferias das cidades - e a violência urbana, ao explorar a vinculação entre a desorganização social e a desorganização urbana e a tendência para a ocorrência de determinados delitos naquelas áreas.

Nessa linha de entendimento defendemos, pois, a ideia segundo a qual ao lado do melhor aparelhamento das Instituições que fazem parte do Sistema Formal de Controle Social, assim como, através de um redimensionamento dos gastos públicos securitários, deve-se buscar, no âmbito das políticas criminais, o desenvolvimento de políticas públicas que priorizem o combate à violência estrutural e, como via absolutamente certa de consequência, a diminuição da violência criminal.

Com a sociologia desenvolvida pela Escola de Chicago acabamos por concluir que são profundas as inter-relações entre a desorganização social, a desorganização urbana e a prática de determinados crimes, podendo-se, em razão de características determinadas espacialmente, identificar áreas mais propensas ao cometimento de delitos específicos e, por essa via, elaborar ações planejadas que visem combater esse tipo de violência.

Em síntese, compactuamos com o posicionamento dos sociólogos de Chicago, entendendo pertinente o entendimento segundo o qual, com o desenvolvimento urbano das cidades as camadas mais pobres da população foram sendo empurradas para a periferia, onde a urbanização era - e continua sendo - precária, configurando-se como áreas deterioradas, com infraestrutura 
absolutamente precária, tendo tal deslocamento causado a ruptura de seus laços familiares e comunitários, dificultando o controle social informal, estabelecendo-se, assim, a somatória destas características como um profícuo caldo de cultura para o cometimento de crimes, mormente contra a pessoa, patrimoniais e de tráfico de drogas.

No que pertine à possibilidade de utilização de tal teoria nas cidades brasileiras, concluímos que em tal contexto são totalmente aplicáveis as concepções interacionistas, ou seja, que as orientações de conduta do indivíduo no meio em que vive acabam por se direcionar em função do entorno no qual habita, no ambiente físico e nas relações intersubjetivas que lá desenvolve a partir do que estes significam para ele, ou seja, tal significado surge como consequência da interação social que este indivíduo mantém com seu próximo, com as pessoas e seu ambiente de convivência, sendo tais significados manipulados e modificados mediante um processo interpretativo desenvolvido por este ao defrontar-se com as situações que vai encontrando em sua rotina diária.

Assim sendo, concluímos que em relação às cidades brasileiras, que indistintamente apresentam bolsões de pobreza urbana, localizados no seio dos centros urbanos ou na periferia destas, imperam a precariedade dos serviços urbanos e a baixa oferta de trabalho que, aliados à escolarização deficiente e à precarização do suporte social e institucional no interior de famílias recém-constituídas, acaba por sedimentar, em tais áreas, populações expostas às situações de risco, criando condições diretas ou indiretas para a explosão de conflitos violentos, quer na esfera da criminalidade, quer na esfera de combate à mesma, quando do exercício da violência institucional em suas formas múltiplas, sobretudo à exercida pelas instituições policiais na sua função de controle social.

Corroboramos, portanto, integralmente com a hipótese que deu suporte científico ao presente texto, segundo a qual, são estreitas as relações entre desorganização social e desorganização urbana e, destas, com a prática de determinados delitos vinculados espacialmente, quer na origem, quer nas consequências, ou em ambos na mesma localidade.

Por fim, conforme prometido no início do trabalho e, talvez, como a parte mais importante deste, apresentamos caminhos que devem ser trilhados para enfrentamento dos problemas oriundos das interrelações entre desorganização social, desorganização urbana e criminalidade.

Por essa via, concluímos que o desenvolvimento de políticas públicas com investimentos nas áreas de organização pela via da inclusão social e urbanização nas comunidades, além de serem direitos constitucionalmente previstos, apresentam impacto positivo em todos os setores da sociedade, vez que direcionados ao combate da violência estrutural e, por essa via, acabam por privilegiar o reconhecimento da cidadania.

Para tanto, entendemos que deva ser adotada uma linha de desenvolvimento de Políticas Públicas de Segurança não repressivas, nas quais o Poder Político acabe por se aproximar de maneira 
bastante incisiva dos ditames previstos constitucionalmente, em que há claramente um direcionamento pela busca de efetivação de ações inclusivas que venham a concretizar os direitos e garantias, mormente os de cunho social, assegurados abstratamente pela Carta Magna.

Ante as exigências acima apontadas e pela linearidade do que neste trabalho temos articulado, ou seja, intervenções ambientais de cunho social e urbanístico como políticas públicas para enfrentamento da violência - estrutural e criminal - e criminalidade, concluímos que o caminho a ser seguido passa, sem a menor sombra de dúvidas, pelo aumento da participação municipal na implementação e execução de políticas públicas que tenham a capacidade de diminuir a violência e a criminalidade e, portanto, incrementar resultados positivos em nível global de segurança pública.

Em síntese e como forma de finalização do trabalho, defendemos a ideia de que entre as mais variadas possibilidades para enfrentamento da violência que se concentra em locais espacialmente determinados e cuja prática reiterada acaba por criar uma cultura criminosa que se expande e alastra por toda a cidade, está o desenvolvimento de políticas públicas que reflitam inclusão social, quer pelo resgate dos vínculos e valores sociais, quer pela recuperação das áreas degradas, em obediência ao que prevê a Constituição Federal como direitos fundamentais de todo cidadão e que tais políticas sejam efetivadas, preferencialmente, pelos Municípios.

\section{REFERÊNCIAS}

ABBOTT, Andrew. Of Time and Space: The Contemporary Relevance of the Chicago School. Social Forces, vol. 75, n. 4, Jun.1997, p. 1149-1182.

ADORNO, Sérgio. Violência urbana, justiça criminal e organização social do crime. São Paulo: NEVI/USP, 1990.

jul./dez. 2002, p. 84-135

Exclusão socioeconômica e violência urbana. Sociologias, Porto Alegre, ano 4, no 8,

ALMEIDA, Suely Souza de; SOARES, Laura Tavares; POUGY, Lilia Guimarães. Da avaliação de programas sociais à constituição de políticas públicas: a área da criança e do adolescente. Rio de Janeiro: Ed. UFRJ, 2008.

ANDRADE, Luciana Teixeira de, SOUZA, Dalva Borges de, FREIRE, Flávio Henrique Miranda de A. (Orgs.) Homicídios nas regiões metropolitanas. Rio de Janeiro: Letra Capital, 2013.

ANDRADE, Vera Regina Pereira. Sistema penal máximo $X$ cidadania mínima: códigos da violência na era da globalização. Porto Alegre: Livraria do Advogado, 2003. 
BARATTA, Alessandro. Criminologia crítica e crítica do Direito Penal: introdução à sociologia do direito penal. Tradução de Juarez Cirino dos Santos. 2. ed. Rio de Janeiro: Freitas Bastos, 1999.

BATELLA, Wagner Barbosa, DINIZ, Alexandre Magno Alves. Análise espacial dos condicionantes da criminalidade violenta no Estado de Minas Gerais. Disponível em: http://www.scielo.br/pdf/sn/v22n1/11.pdf Acesso em 08/02/2018.

BATISTA, Nilo. Punidos e mal pagos: violência, justiça, segurança pública e direitos humanos no Brasil de hoje. Rio de Janeiro: Revan, 1990, 191 p.

BEATO FILHO, Claudio Chaves, Crime e cidades. Belo Horizonte: Editora UFMG, 2012.

. REIS, Ilka A. Desigualdade, desenvolvimento socioeconômico e crime. In:

HENRIQUES, R. (Org.). Desigualdade e Pobreza no Brasil. Rio de Janeiro: IPEA, 2000. P. 385-403.

. PEIXOTO, Betânia Totino. Há nada certo. Políticas sociais e crime em espaços urbanos. In: Prevenção da violência: o papel das cidades. SANTO SÉ, João Trajano. Rio de Janeiro: Civilização Brasileira, 2005.

BECKER, H. Conferência A Escola de Chicago. In: Mana - estudos de Antropologia Social, vol. 2, n. 2, out. 1996.

BERGALLI, Roberto. Sistema penal y problemas sociales. Valencia: Tirant lo Blanch, 2003.

BLUMER, Herbert. Simbolic interacionism: perspective and method. Berkeley: University of California Press, 1986.

BRAGA, Adriana. GASTALDO, Édison. O legado de Chicago e o estudo de recepção, usos e consumos midiáticos. Revista FAMECOS, Porto Alegre, no 39, ago. 2009, p. 78-84.

BURGESS, Ernest W. O crescimento da cidade: introdução a um projeto de pesquisa, in: PIERSON, Donald. Estudos de Ecologia Humana (org.). São Paulo: Martins, 1970, p. 353-368.

BURSIK JR., Robert J. Social disorganization and theories of crime and delinquency: problems and prospects. Criminology, v. 26, issue 4, novembro de 1988, p. 519-552. Disponível em: http://onlinelibrary.wiley.com/doi/10.1111/j.1745-9125.1988.tb00854.x/abstract Acesso em 01/03/2018.

CABRAL DE LIRA, Anneliese Heyden. Avaliação da qualidade de vida urbana dos condomínios horizontais da cidade de João Pessoa - PB. 2014. Dissertação (Mestrado em Direito) - Universidade Federal da Paraíba. João Pessoa, 2014.

CALDEIRA, Teresa Pires do Rio. Cidade de muros. Crime, segregação e cidadania em São Paulo. São Paulo: EDIUSP, 2000.

CAOP-CRIM. Estatísticas das ocorrências de CVLI na grande llha de São Luís no ano de 2017. Janeiro de 2018, Disponível em: nahttps://www.mpma.mp.br/index.php/lista-de-noticias-gerais/13960caop-crim-divulga-relatorio-sobre-violencia-na-ilha-de-sao-luis-em-2017 Acesso em 22/02/ 2018.

CAPLAN, Joel. Focus on place, not people to prevent crime. Youtube, 25 de abril de 2016. Disponível em: https://www.youtube.com/watch?v=5hKWLY1IZrs\&t=32s. Acesso em 18/02/2018. 
CÁRDIA, Nancy, SCHIFFER, Sueli. Violência e desigualdade social. Ciência e Cultura, São Paulo, v. 54, no. 1, 2000, p. 25-31.

CARMONA, Paulo Afonso Cavichioli. Violência X Cidade. $O$ papel do Direito Urbanístico na violência urbana. São Paulo: Marcial Pons, 2014.

CARVALHO, Francisco, "Da Ecologia Geral à Ecologia Humana», Forum Sociológico [Online] Disponível em: http://journals.openedition.org/sociologico/1680 2007. Acesso em 07/02/18.

CARVALHO, Virgínia Donizete de; BORGES, Livia de Oliveira; REGO, Denise Pereira do. Interacionismo simbólico: origens, pressupostos e contribuições aos estudos em Psicologia Social. Psicologia, Ciência e Profissão, Brasília, v. 30, n. 1, p. 146-161, mar. 2010. Disponível em http://pepsic.bvsalud.org/scielo.php?script=sci_arttext\&pid=S14148932010000100011\&lng=pt\&nrm =iso Acesso em 07/02/18.

CASTELETTO, Hugo Santana. Estrutura socioespacial de Maringá e os territórios de criminalidade. 2014. Dissertação (Mestrado em Direito) - Universidade Estadual de Maringá. Maringá, 2014.

CERQUEIRA, Daniel; LOBÃO, Waldir. Determinantes da criminalidade: arcabouços teóricos e resultados empíricos. Revista de Ciências Sociais, vol. 47, n. 2, 2004, p. 233-269.

CHICAGO AREA PROJECT. Disponível em http://www.chicagoareaproject.org/about-us Acesso em 22/02/2018.

COHEN, Albert K. Delinquent boys: the culture of the gang. In: NEWBURN, Tim. (Org.) Key readings in criminology. London: Willan Publishing, 2009, p. 194-198.

COULON, Alain. A Escola de Chicago. Campinas, São Paulo: Papirus, 1995.

DELGADO, Rodrigo Mendes. Espaços urbanos e criminalidade: um estudo do ambiente urbano como fator criminogênico. 2014. Disponível em: https://jus.com.br/artigos/35064/espacos-urbanose-criminalidade Acesso em 17 de fevereiro de 2018.

DEWEY, John. Disponível em: https://deweypragmatismo.wordpress.com/sobre-john-dewey/ Acesso em 01/02/2018.

DIAS, Jorge de Figueiredo. ANDRADE, Manuel da Costa. Criminologia - o homem delinquente e a sociedade criminógena. 2a reimpressão. Coimbra: Coimbra Editora, 1997.

DINIZ, Alexandre M. A. Migração, desorganização social e violência urbana em Minas Gerais. 2005. Disponível em http://revistas.ufpr.br/raega/article/view/3443 Acesso em 05/02/2018.

EVANGELISTA, Felipe Camelo de Freitas. A criminalidade e o planejamento ambiental urbano.

Veredas do Direito: Direito Ambiental e Desenvolvimento Sustentável, Belo Horizonte, v. 9, n. 17, dez. 2012. Disponível em:

http://www.domhelder.edu.br/revista/index.php/veredas/article/view/245 Acesso em: 09/02/18.

Famílias em clima de tensão. O Imparcial. São Luís, 6 de jan. 1997, Ano LXIX, no 22.658, p. 9.

FARIA, Antônio Hot Pereira de, ALVES, Diego Filipe Cordeiro, FERREIRA, Tomás Hilário Cardoso. Além da territorialidade. Uma análise espacial da atuação de guangue em Minas Gerais. In: Anais do XI

Encontro Nacional da ANPEGE, 2015. 
FELGUERAS Sérgio. Geração à rasca. Lisboa: Chiado Editora, 2016.

FELIX, Sueli Andruccioli. A Geografia do Crime: interdisciplinaridade e relevâncias. Marília: UNESP/Publicações, 2002.

FERREIRA, Ignez Costa Barbosa, PENNA, Nelba Azevedo. Território da violência: um olhar geográfico sobre a violência urbana. Revista da GEOUSP - Espaço e Tempo. São Paulo, n. 18, 2005, p. 155-168.

FREITAS, Wagner Cinelli de Paula. Espaço urbano e criminalidade: lições da Escola de Chicago. São Paulo: IBCCRIM, 2002.

GOODIN, Robert E., REIN, Martin, MORAN Michael. The Public and its policies. In: MORAN, Michel, REIN, Martin, GOODIN, Robert F. The Oxford Handbook of Public Policy. Oxford: Oxford University Press, 2008.

GUIMARÃES, Claudio Alberto Gabriel. Funções da pena privativa de liberdade no sistema penal capitalista. 2 ed., Rio de Janeiro: Revan, 2007.

. Reflexões acerca do controle social formal: rediscutindo os fundamentos do direito de punir. Revista da Faculdade de Direito da UERJ-RFD. Rio de Janeiro, v. 1, n. 23, 2013. Disponível em: http://www.e-publicacoes.uerj.br/index.php/rfduerj/article/view/4894 Acesso em 02 de fevereiro de 2018.

; PEREIRA, Paulo Fernando Soares. Reflexões a respeito da necessidade de participação dos Municípios na formulação e implementação de políticas de segurança pública. Revista Quaestio luris, v. 07, n. 02, Rio de Janeiro, 2014. p. 812-839.

IPEA Instituto de Pesquisa Econômica e aplicada. Relatório final de Pesquisa. Atlas da Violência 2017. 2017 Disponível em: http://www.ipea.gov.br/atlasviolencia/download/2/2017 Acesso em 12/02/18.

JACCOUD, Luciana; CARDOSO JR., José Celso. Políticas Sociais no Brasil: Organização, abrangência e tensões da ação estatal. In: JACCOUD, Luciana (org.) Questão social e políticas sociais no Brasil contemporâneo. Brasília: IPEA, 2005.

JOAS, H. Interacionismo simbólico. In: GIDDENS, A. \& TURNER, J. (Orgs.) Teoria Social Hoje. São Paulo: Editora UNESP, 1999, p. 127-174.

KAHN, Tulio. Indicadores em prevenção municipal de criminalidade. In: SENTO-SÉ, João Trajano (org.). Prevenção da violência: o papel das cidades. Rio de Janeiro: Civilização Brasileira, 2005.

KLEINSCHMITT, Sandra Cristiana, LIMA, Jandir Ferrera de, WADI Yonissa Marmitt. Relação entre o crescimento da desigualdade social e dos homicídios no Brasil: o que demonstram os indicadores? 2011. Disponível em: http://www.epublicacoes.uerj.br/index.php/intersecoes/article/viewFile/4605/3404 Acesso em 19/02/18.

LIMA, Patrícia Verônica P. S., SOUSA, Janaildo Soares de, ARAUJO SOBRINHO, Adauto Morais de, FAUSTINO, Jennifer Cícera dos Santos; CASIMIRO FILHO, Francisco. Gestão Municipal da Segurança Pública: Responsabilidade dos municípios brasileiros no combate a violência. Revista de Políticas Públicas, São Luís, v. 18, n. 2. Jul./dez. 2014, p. 399-414.

LIRA, Pablo. Análise dos crimes violentos e da tipologia socioespacial da Região Metropolitana da grande Vitória - RMGV. In: Anais do VII Congresso Brasileiro de Geógrafos. Vitória-ES, 2014. 
Geografia do crime. Estudo do Índice de Violência Criminalizada - IVC e da tipologia socioespacial. E-metropolis, ano 23, n. 5, dez. 2015. Disponível em: http://emetropolis.net/system/artigos/arquivo_pdfs/000/000/175/original/emetropolis_n23_art1.p df?1450464274 Acesso em 16/02/2018.

MASSENA, Rosa Maria Ramalho. Distribuição especial da criminalidade violenta na região metropolitana do Rio de Janeiro. Revista Brasileira de Geografia, Rio de Janeiro, v. 48, n. 3, p. 285330, jul./set. 1986.

MEAD, George Herbert. Mind, self and society from the standpoint of a social behaviorist. Chicago: University of Chicago Press, 1934.

MELHEM, Patrícia Manente. Cidade grande, mundo de estranhos: Escola de Chicago e "comunidades guarda-roupa". Disponível em: https://jus.com.br/artigos/24879/cidade-grandemundo-de-estranhos-escola-de-chicago-e-comunidades-guarda-roupa/2 acesso em 10/02/2018.

MELO, Silas Nogueira de, MATIAS, Lindon Fonseca. Geografia do crime e criminologia ambiental: teorias da desorganização social e atividade de rotina. 2015. Disponível em: http://www.enanpege.ggf.br/2015/anais/arquivos/2/38.pdf Acesso em 05/02/2018.

MELOSSI, Dario. El Estado de control social. Madrid: Siglo Veintiuno, 1992.

MISSE, M. "Cinco teses equivocadas sobre a criminalidade urbana no Brasil: uma abordagem crítica, acompanhada de sugestões para uma agenda de pesquisas". Série Estudos, n. 91, Rio de Janeiro, 1995. Disponível em: https://www.tigweb.org/images/resources/tool/docs/1837.pdf Acesso em:25/02/2018.

MORAN, Michel, REIN, Martin, GOODIN, Robert F. The Oxford Handbook of Public Policy. Oxford: Oxford University Press, 2008.

NASCIMENTO, Edna Maria Magalhães do. Pragmatismo: uma filosofia da ação. 2010. Disponível em: http://leg.ufpi.br/subsiteFiles/ppged/arquivos/files/VI.encontro.2010/GT.20/GT_20_01_2010.pdf Acesso em 05/02/2018.

NEWBURN, Tim. (Org.) Key readings in criminology. London: Willan Publishing, 2009.

OLIVEIRA, Edmundo. A Identidade Humana do Crime. Belém: CEJUP, 1987.

PAIXÃO, Luiz Antonio. A violência urbana e a sociologia: sobre crenças e fatos e mitos e teorias e políticas e linguagens. Religião e sociedade, v. 15, n. 1, 1990. p. 68-81.

PARK, Robert Ezra. On Social Control and Collective Behavior. Chicago: University of Chicago Press, 1967.

, BURGESS, Ernest W. Introduction to the science of sociology. Chicago: The University of Chicago Press, 1921.

\section{MCKENZIE, R. The City. Suggestions for investigation of human behavior in}

the urban environment. Chicago: Midway, 1984.

PAVARINI, Massimo. Control y dominación. Teorías criminológicas burguesas y proyecto hegemónico. 6 ed. Madrid: Siglo Veintiuno Editores, 1998,. 
PLANO NACIONAL DE SEGURANÇA PÚBLICA. 2000. Disponível em: http://www.observatoriodeseguranca.org/files/PNSP\%202000.pdf Acesso em: 21 de fevereiro de 2018.

PLANO NACIONAL DE SEGURANÇA PÚBLICA. 2017. Disponível em: http://www.justica.gov.br/news/plano-nacional-de-seguranca-preve-integracao-entre-poderpublico-e-sociedade/pnsp-06jan17.pdf Acesso em 21 de fevereiro de 2018.

POLÍTICA NACIONAL DE SEGURANÇA PÚBLICA. 2018. Disponível em: http://www.justica.gov.br/news/politica-nacional-de-seguranca-publica/minuta_pnasp.pdf Acesso em 22 de fevereiro de 2018.

RAMOS, Edvaldo Fernandes. A cidade pensada teoricamente. Caderno de Geografia, v. 25, n. 44, 2015.

RIBEIRO, Eduardo, CANO, Inácio. Civitas, Porto Alegre, v. 16, n. 2, abr./jun. 2016, p. 285-305.

SANTOS, Juarez Cirino dos. As raízes do crime: um estudo sobre as estruturas e as instituições da violência. Rio de Janeiro: Forense, 1984.

SANTOS, Márcia Andréia Ferreira, Geografia dos crimes violentos em Uberlândia - MG. Revista da ANPEGE, v. 12, n. 19, jul./dez. 2016, p. 166-182.

SARAIVA, Railda. Poder, violência e criminalidade. Rio de Janeiro: Forense, 1989.

SHAW, Clifford R., McKAY, Henry D. Juvenile delinquency and urban areas - a study of rates of delinquents in relation to differential characteristics of local communities in American cities. Chicago: The University of Chicago Press, 1942.

SHECAIRA, Sérgio Salomão. Criminologia. 4. ed. São Paulo: Editora Revista dos Tribunais, 2012.

SIQUEIRA, Maria da Penha. Industrialização e empobrecimento urbano: caso da grande vitória 19501980. Vitória: Edufes, 2001.

SKOGAN, Wesley G. Disorder and crime. In: WELSH, Brandon C., FARRINGTON, Davia P. The Oxford Handbook of Crime Prevention. Oxford: Oxford University Press, 2016, p. 173-188.

SOARES, Luis Eduardo. Novas políticas de segurança pública. Revista de Estudos Avançados, vol.17, n. 47, São Paulo, Jan./Abr. 2003.

SOGAME, M. Rudimentos para o exame da urbanização em sua fase crítica: uma aproximação ao conceito de segregação socioespacial. In: Revista geografares. Vitória: Edufes, n. 2, 2001, p. 95-103.

SUTHERLAND, E. The professional thief. Chicago: University of Chicago Press, 1937.

TANGERINO, Davi de Paiva Costa. Crime e cidade: Violência urbana e a Escola de Chicago. Rio de Janeiro: Lumen Juris, 2007.

TEODÓSIO. Armindo dos Santos de Sousa. Escola de Chicago: heranças para o pensamento social contemporâneo sobre as cidades. Trabalho apresentado no XI Congresso Brasileiro de Sociologia. $1 \mathrm{a}$ 5 de setembro de 2003, UNICAMP, Campinas, São Paulo. 
THOMAS, William I. The Unadjusted Girl with cases and standpoint for behavior analysis. New York: Little, Brown \& Co, 1923.

1927. . ZNANIECKI, F. The polish peasant in Europe and America. Nova York: Knopf,

VALENTIN, Fernando Farias, PINEZI, Ana Keila Mosca. Indivíduo e sociedade no pensamento social da Escola de Chicago. Revista Agenda Social, v. 3, n. 6, S/D, disponível em: http://www.revistaagendasocial.com.br/files/journals/Revistas/REVISTA_AGENDA_SOCIAL_V6_N3.p df Acesso em 14 de fevereiro de 2018.

VENDRAMINI, Janio. Segurança pública nas grandes cidades brasileiras. São Paulo: Navegar Editora, 2010.

VESENTINI, José William. Brasil - sociedade e espaço. 21ạ edição. São Paulo: Editora Ática, 1994.

WAISELFISZ, Júlio Jacobo. Mapa da violência 2016: homicídio por armas de fogo no Brasil. Rio de Janeiro: FLACSO, 2016. Disponível em:

http://www.mapadaviolencia.org.br/pdf2016/Mapa2016_armas_web.pdf Acesso em 19 de fevereiro de 2018.

WELSH, Brandon C., FARRINGTON, David P. The Oxford Handbook of Crime Prevention. Oxford: Oxford University Press, 2016.

ZAFFARONI, Eugenio Raul. Globalização e sistema penal na América Latina: da segurança nacional à urbana. Discursos sediciosos. Crime, direito e sociedade. Rio de Janeiro, ano 2, n. 4, p. 25-36, 2o. Semestre de 1997.

Trabalho enviado em 23 de novembro de 2019

Aceito em 03 de março de 2021 